This is the accepted version of the article:

Souri B., Hayati P., Rezvani A.R., Mendoza-Meroño R., Janczak J.. A copper(II) zig-zag metal-organic coordination polymer: synthesis, crystal structure, topology study, hirshfeld surface analysis and survey different conditions on morphology of a novel nano structure [ $\mathrm{Cu}(\mathrm{L})(\mathrm{SCN})(\mathrm{H} 2 \mathrm{O}) 2]$ n. $2 \mathrm{H} 2 \mathrm{O}$. I norganic and Nano-Metal Chemistry, (2019). . : - . 10.1080/24701556.2019.1662040.

Available at:

https://dx.doi.org/10.1080/24701556.2019.1662040 


\title{
A copper(II) zig-zag metal-organic coordination polymer: synthesis, crystal structure, topology study, hirshfeld surface analysis and survey different conditions on morphology of a novel nano structure $\left[\mathrm{Cu}(\mathrm{L})(\mathrm{SCN})\left(\mathrm{H}_{2} \mathrm{O}\right)_{2}\right]_{n} \cdot 2 \mathrm{H}_{2} \mathrm{O}$
}

\author{
Bagher Souri ${ }^{a}$, Payam Hayati $^{\mathrm{b}}$, Ali Reza Rezvani ${ }^{\mathrm{a}}$, Rafael Mendoza-Meroño ${ }^{c}$, and Jan Janczak ${ }^{\mathrm{d}}$ \\ ADepartment of Chemistry, Faculty of Sciences, University of Sistan and Baluchestan, Zahedan, Iran; "Catalan Institute of Nanoscience and \\ Nanotechnology ( ICNR), CSIC and The Barcelona Institute of Science and Technology, Barcelona, Spain; 'Departamento de Química Fisica y \\ Analítica, Universidad de Oviedo, Oviedo-CINN, Spain; Institute of Low Temperature and Structure Research, Polish Academy of Sciences, \\ Wroclaw, Poland
}

\begin{abstract}
One copper(II) coordination polymer compound [Cu(L) $\left.(\mathrm{SCN})\left(\mathrm{H}_{2} \mathrm{O}\right)_{2}\right]_{n} \cdot 2 \mathrm{H}_{2} \mathrm{O}$ (1) where $\mathrm{L}$ stand for 2-pyridinecarboxylic acid, was synthesized following two different experimental methods, branch tube and sonochemical irradiation nano methods. Independently of the methodology used, the same crystalline phase is obtained for each compound. Single crystal X-ray analyses on compound $\mathbf{1}$ showed that $\mathrm{Cu}^{2+}$ ions are 6-coordinated. Additionally, $\mathrm{H}$-bonds incorporate the zig-zag chains in 1 into $2 \mathrm{D}$ (along $(1,1,0$ direction) frameworks. Topological analysis shows that the compound $\mathbf{1}$ is $2 \mathrm{Cl}$ net. Hirshfeld surface analysis of compound $\mathbf{1}$ was studied. Also, theoretical and experimental morphology were studied. The thermal stability of compound $\mathbf{1}$ was studied by thermal gravimetric. Finally, the role of reaction time and temperature on growth and final morphology of the structures obtained by sonochemical irradiation are investigated. The results indicated that particle size was reduced with increasing sonication power, temperature, sonication time and decreasing concentration of reactant.
\end{abstract}




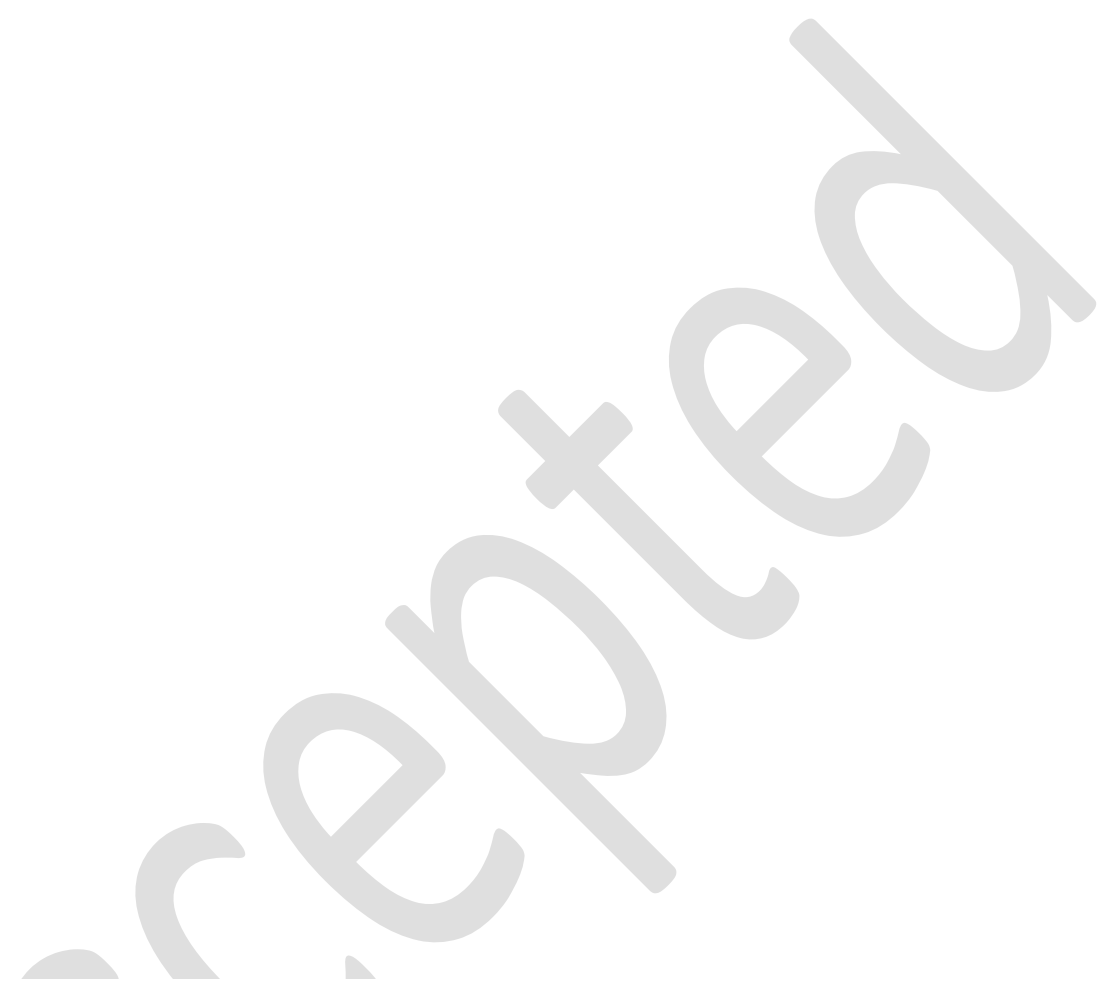

\section{Introduction}

The construction and designs of coordination polymer compounds (CPCs) are of current interest in the fields of supramolecular chemistry and crystal engineering. ${ }^{[1-3]}$ This interest arises using their intriguing various architectures and topologies $^{[3-6]}$ Furthermore, research on the synthesis and characterization of metal-organic coordination polymers is greatly motivated by their potential applications induding catalysis, $^{[3-10]}$ gas storage, ${ }^{[3,5,6,8-10]}$ magnetism, ${ }^{[3-7,9,0]}$ molecular sensing, ${ }^{[3,5,9,10]}$ non-linear optics, ${ }^{[4,57,10]}$ ion-exchange, ${ }^{\mid 3,4,6]}$ electric conductivity, ${ }^{[47.9]}$ molecular separation, ${ }^{[8.9]}$ host-guest chemistry, ${ }^{|4,9|}$ and medicine. ${ }^{|5|}$ Therefore, rational design and synthesis of materials with specific networks has become a major research concem. ${ }^{[3]}$ Numerous coordination polymers with a wide variety of structural motifs have been prepared with the variation of reagents and reaction conditions. ${ }^{|6,10|}$ Copper materials are attracting an increasing number of interests due to their wildly applications in the field of catalyst, chemical sensors, luminescence, and so on. ${ }^{[11-18]}$

A number of different synthetic approaches have been offered for the preparation of coordination compounds. ${ }^{[19]}$ Some of them are (1) slow diffusion of the reactants into a polymeric matrix, (2) diffusion from the gas phase, (3) evaporation from the solvent at ambient or reduced temperatures, (4) precipitation or recrystallisation from a mixture of solvents, (5) temperature controlled cooling, (6) hydrothermal synthesis, and (7) sonochemistry method ${ }^{\mid 20-24]}$

Sonochemistry method is easy, fast, and enables highly accurate control of synthesis parameters induding time, energy input, and $\mathrm{pH}$. Furthermore, the use of ultrasonic irradiation induces particle deagglomeration, which increases the surface area of the materials. ${ }^{|z-30|}$ The sonochemical method enables use of the surface charge-induced hetero aggregation strategy, based on the dispersion of particles by physical methods and adjustment of the $\mathrm{pH}$ of the medium to a value between the points of zero charge of the materials. This maximizes the electrostatic attraction together, favoring the effective formation of heterojunctions and control of the morphology. ${ }^{|31-32|}$

Control of nano-sized building blocks therefore is essential for the future success of science and technology in the nanoscale realm. ${ }^{[33]}$ With all these facts in mind the need for the development of synthetic methods in which the size and morphologies of nanostructured materials could be controlled becomes obvious both from the viewpoint of basic 
sciences as well as applied technology. ${ }^{[35-39]}$ The effects of ultrasound radiation on chemical reactions were reported in recent works. ${ }^{\mid 40-45]}$

Until now, examples of $\left[\mathrm{Cu}_{2}\left(\mathrm{~L}_{1}\right)(\mu-1,3-\mathrm{SCN})_{2}(\mathrm{SCN})\right]_{\mathrm{n}}$ $\left(\mathrm{L}=4^{\prime} \text {-(4-pyridyl)-2,2' } 6^{\prime}, 2^{\prime \prime} \text {-terpyridine }\right)^{\mid 46]}$ trans$\left[\mathrm{Cu}(\mathrm{NCS})_{2}(\mathrm{Py})_{2}\right]\left(\mathrm{Py}=\mathrm{C}_{5} \mathrm{H}_{5} \mathrm{~N}\right),{ }^{, 47]}\left[\mathrm{Cu}(\mathrm{NCS})_{2}(4-\mathrm{MeAPy})_{2}\right]_{\mathrm{n}}(4-$ $\mathrm{MeAPy}=4$-methylaminopyridine), ${ }^{|+8|} \quad \mathrm{K}_{2}\left[\mathrm{Cu}_{2}(\mathrm{sal}-\mathrm{aa})_{2}\right.$ $\left.(\mu-\mathrm{NCS})_{2}\right] \mathrm{n} \cdot \mathrm{H}_{2} \mathrm{O} \quad\left(\right.$ sal-aa $=\mathrm{N}$-salicylideneamino acid), ${ }^{|49|}$ copper(II) coordination polymer complex with different ligand are reported. However, the synthesis of lead-based ID coordination polymers still represents a challenge. In this work, we would like to describe the rapid synthesis of nanocrystals of a copper(II) ID CPC, $\left[\mathrm{Cu}(\mathrm{L})(\mathrm{SCN})\left(\mathrm{H}_{2} \mathrm{O}\right)_{2}\right]_{\mathrm{n}} \cdot 2 \mathrm{H}_{2} \mathrm{O}$ (1), ( $\mathrm{L}=2$-pyridinecarboxylic acid). The power of ultrasound irradiation, sonicating time, temperature of reaction, and concentration of initial reactants were the parameters evaluated for reaching the optimized condition. Scanning electron microscopy (SEM) and powder X-ray diffraction (PXRD) were used for the characterization of the products. Additionally, we have investigated the influence of different properties (sonication power, reaction time, temperature, and concentration of reactant) on the partide morphology and size. This was achieved by using a sonochemical method.

\section{Experimental}

\section{Materials and physical techniques}

Starting reagents for the synthesis were purchased and used without any purification from industrial suppliers (SigmaAldrich, Merck and others). Elemental analyses (carbon, hydrogen, and nitrogen) were performed employing a Heraeus Analytical Jena, Multi EA 3100 CHNO rapid analyzer (Analytik Jena AG, Böblingen, Germany). Fourier transform infrared spectra were recorded on a FT-IR JASCO 680 -PLUS spectrometer as $\mathrm{KBr}$ pellets in the $4000-400$ $\mathrm{cm}^{-1}$ spectral range and Bruker Tensor 27 FT-IR with a single window reflection of diamond attenuated total reflectance (model MKII Golden Gate, Specac) and the OPUS data collection program software. The instrument is equipped with a room temperature detector, and a mid-IR source (4000-400 $\mathrm{cm}^{-1}$ ). Since it is a single beam instrument, it was needed to run a background spectrum in air before the measurement. Single crystal X-ray diffraction experiments were carried out for compound 1 with $\operatorname{MoK} \alpha$ radiation $(\lambda=0.71073 \AA)$ at ambient temperature. A micro focused Rigaku mm003 source with integrated confocal caxFlux double bounce optic and HPAD Pilatus $200 \mathrm{~K}$ detector was used for 1 while for two data were measured on a BrukerNonius Kappa CCD diffractometer. The structures were solved by direct methods and refined by full matrix least squares on $F^{2}$. All non-hydrogen atoms were refined anisotropically. The hydrogen atoms were included with fixed isotropic contributions at their calculated positions determined by molecular geometry, except for the oxygen bonded hydrogen atoms, which were located on a difference Fourier map and refined riding on the corresponding atoms. Computing details: data collection, cell refinement and data reduction: CrystalClear-SM expert $2.1 \mathrm{~b} 43^{\mid 50)}$; program(s) used to solve structure: SHELXT ${ }^{[51]}$; $\operatorname{program}(s)$ used to refine structure: SHEL.XL-2014/7 $7^{[51]}$; molecular graphics: PLATON ${ }^{[52]}$; reduction of data and semiempirical absorption correction: SADABS program ${ }^{[53]}$; direct methods (SIP97 program ${ }^{[54]}$ ); full-matrix least-squares method on $F^{2}$ : SHELXL-97 program $^{\lfloor 5]}$ with the aid of the programs WinGX ${ }^{[56]}$ and Olex.$^{[57,58]} \mathrm{X}$-ray powder diffraction (XRD) measurements were performed using an $\mathrm{X}^{3}$ pert diffractometer manufactured by Philips with monochromatized Cuka radiation and simulated XRD powder patterns based on single crystal data were prepared using the Mercury software. ${ }^{[57]}$ The samples were characterized with a scanning electron microscope (SEM; FEI Quanta 650 FEG) in mode operation of secondary electrons (SE) with a beam voltage between 15 and $20 \mathrm{KV}$. The samples were prepared by deposition of a drop of the material previously dispersed in properly solvents on aluminum stubs followed by evaporation of the solvent under ambient conditions. Before performing the analysis, the samples were metalized by depositing on the surface a thin platinum layer $(5 \mathrm{~nm})$ using a sputter coater (Leica EM ACE600). A multi wave ultrasonic generator (ultrasonic homogenizer-UP 400-A, IRAN and Elmasonic [Elma] $\$ 40 \mathrm{H}$ ), equipped with a converter/ transducer and titanium oscillator (horn), $12.5 \mathrm{~mm}$ in diameter, operating at $20 \mathrm{kHz}$ with a maximum power output of $400 \mathrm{~W}$, were used for the ultrasonic irradiation. Melting points were measured on an electrothermal 9100 apparatus and are uncorrected.

\section{Synthesis of $\left[\mathrm{Cu}(\mathrm{L})(\mathrm{SCN})\left(\mathrm{H}_{2} \mathrm{O}\right)_{2}\right]_{n} .2 \mathrm{H}_{2} \mathrm{O}$ (1) as single aystals}

Initially, compound $\mathbf{1}$ was synthesized by the branch tube method. Branched tube equipment included on two different parts: (a) Oil bath and (b) Tube. The temperature of oil bath has been adjusted at $60^{\circ} \mathrm{C}$. It should be noted which temperature is the most important parameters in this equipment, because the difference temperature between oil bath

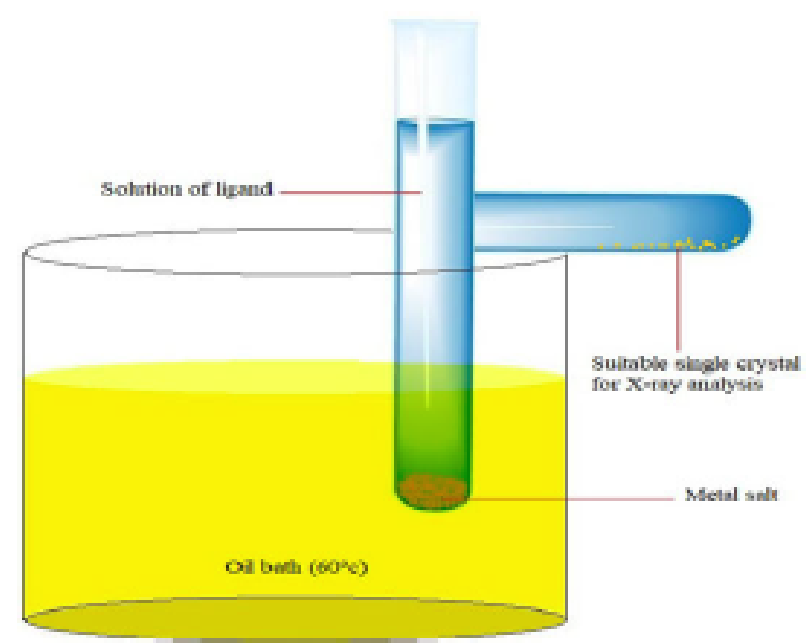

Figure 1. Depiction of the branched tube for symtheses and isolation of single aystals of the meta coordinaton supamolecular. 


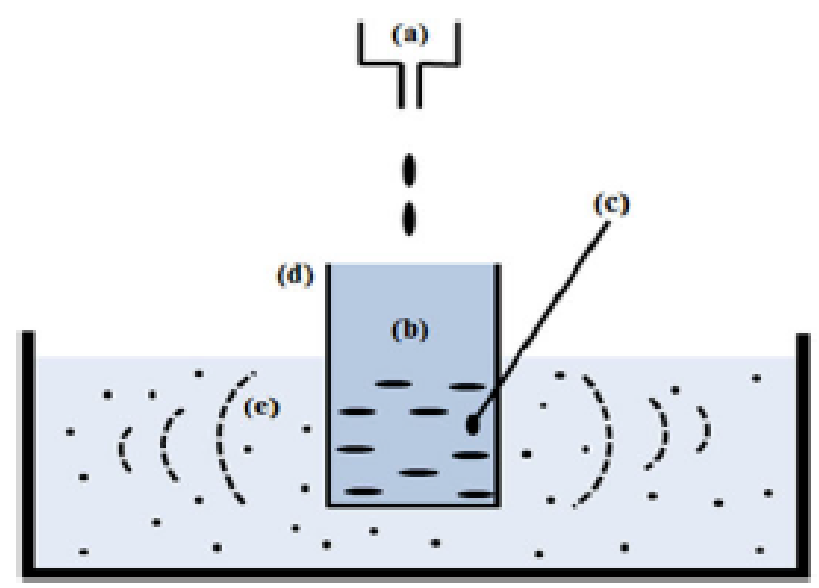

Figure 2. Schemafc of the experimental setup used for the sonochemical reactions (a) mixture of ligand and coumter ion, (b) metal sat solution, (c) thermameter, (d) reaction cell, (e) ultosound bath.

and lateral part (at room temperature) led to make convection flow. Reactants moved up to bottom in glass, spontaneously. In fact convection flow has role of the stirrer. Quality crystals were synthesized by this method after one week. An important advantage of this method in comparison with other crystallization methods which is reactant materials are placed in the bottom of the solvent without dissolving and they react slowly and finally good crystals were obtained (Figure 1).

$\mathrm{Cu}\left(\mathrm{NO}_{3}\right)_{2} \cdot 2.5 \mathrm{H}_{2} \mathrm{O}$ (1 mmol, $0.232 \mathrm{~g}$ ), 2-pyridinecarboxylic acid (L) (1 mmol, $0.246 \mathrm{~g})$ and $\mathrm{KSCN}(2 \mathrm{mmol}, 0.18 \mathrm{~g})$ were loaded into one arm of a branch tube and both of the arms were filled slowly with water. The chemical bearing arm was immersed in an oil bath kept at $60^{\circ} \mathrm{C}$. Crystals were formed on the inside surface of the arm kept at ambient temperature. After 5 days, colorless crystals were deposited in the cooler arm. The crystals obtained were filtered off, washed with water and air dried. $(0.124 \mathrm{~g}, 39.36 \%$ yield based on final product), product 1 (single crystal): mp > $300{ }^{\circ} \mathrm{C}$. Anal. Calc. for $\mathrm{C}_{7} \mathrm{CuH}_{12} \mathrm{~N}_{2} \mathrm{O}$ S: C: $26.59 \%, \mathrm{H}$ : $3.79 \%$, N: $8.87 \%$, O: $30.39 \%$; Found C: $26.51 \%, \mathrm{H}: 3.28 \%$, N: $8.86 \%$. IR (selected bands for compound 1 ; in $\mathrm{cm}^{-1}$ ): 3441(b), 3075(w), 1647 (s), 1605(s), 1349(s), 776(s) $\mathrm{cm}^{-1}$.

\section{Synthesis of $\left[\mathrm{Cu}(\mathrm{L})(\mathrm{SCN})\left(\mathrm{H}_{2} \mathrm{O}\right)_{2}\right]_{n} \cdot 2 \mathrm{H}_{2} \mathrm{O}$ (1) under ultrasonic irradiation}

The study of sonochemistry is concerned with understanding the effect of ultrasound in forming acoustic cavitation in liquids, resulting in the initiation or enhancement of the chemical activity in the solution. Therefore, the chemical effects of ultrasound do not come from a direct interaction of the ultrasonic sound wave with the molecules in the solution. The simplest explanation for this is that sound waves propagating through a liquid at ultrasonic frequencies do so with a wavelength that is significantly longer than that of the bond length between atoms in the molecule. Therefore, the sound wave cannot affect that vibrational energy of the bond, and can therefore not directly increase the internal energy of a molecule. Instead, sonochemistry arises from
Table 1. Crystal data and structures refinement for $\left(\mathrm{Cu}(\mathrm{L})(\mathrm{SON}) \mathrm{H}_{2} \mathrm{O}_{2} \mathrm{~h}_{\mathrm{h}}\right.$ $2 \mathrm{H}_{2} \mathrm{O}(1)$

\begin{tabular}{|c|c|}
\hline $\begin{array}{l}\text { Empirical formula } \\
\text { Formuls weight }\end{array}$ & $\begin{array}{l}\left.\mathrm{C}_{7} \mathrm{H}_{n} \mathrm{CuN}_{2} \mathrm{O}_{4} \mathrm{~S} \cdot 2, \mathrm{H}_{2} \mathrm{O}\right) \\
315.79 \mathrm{~g} / \mathrm{mol}\end{array}$ \\
\hline Temperature & $100 \mathrm{~K}$ \\
\hline Waveleng th & $071073 \AA$ \\
\hline Crystal system & Orthorhombic \\
\hline Space group & Pbca \\
\hline Unit cell dimensions & $\begin{array}{l}\mathrm{a}=8.6400(1) \AA a=90^{\circ} \\
\mathrm{b}=10.6260(2) \AA, \beta=90^{\circ} \\
\mathrm{c}=26.2969(6), \gamma=90^{\circ}\end{array}$ \\
\hline Volume & $241652(8)^{3}$ \\
\hline$z$ & 8 \\
\hline Crystal sine & $0.33 \times 0.27 \times 0.21(\mathrm{~mm})$ \\
\hline Absorption coefficient & $19.068 \mathrm{Mg} / \mathrm{m}^{2}$ \\
\hline$F(000)$ & 1289 \\
\hline Theta range for data collection & $28^{\circ}-29.6^{\circ}$ \\
\hline$\mu$ & $2 \mathrm{~mm}^{-1}$ \\
\hline \multirow[t]{3}{*}{ lndex ranges } & $-11<h \leq 11$ \\
\hline & $-13 \leq k \leq 13$ \\
\hline & $-36 \leq 1 \leq 34$ \\
\hline$(\sin \theta / \lambda)_{\max }$ & $0694 A^{-1}$ \\
\hline Theta $(\max )$ & $29.6^{\circ}$ \\
\hline Radiafion type & Mo $\mathrm{Ka}$ \\
\hline Refinement method & Full-matrix least-squares on $F^{2}$ \\
\hline Goodness-offit on $F^{2}$ & 1041 \\
\hline \multirow[t]{3}{*}{ Refinement } & $\left.\left.R F^{2}>2 \sigma V^{2}\right)\right]=0.025$ \\
\hline & $\left(w 9 F^{2}\right)=0.064$ \\
\hline & $s=1.00$ \\
\hline$R 1[1]>2 \sigma[0]$ & $25166,3122,2818$ \\
\hline Rint & 0026 \\
\hline Largest dift. peak and hole & -0.37 and $0.35 \mathrm{eA}^{-1}$ \\
\hline $\operatorname{CODC}$ no. & 1552099 \\
\hline
\end{tabular}

\begin{tabular}{|c|c|c|c|}
\hline $\begin{array}{l}\text { Table } \\
\text { [Cu/L)/SCN] }\end{array}$ & $\begin{array}{l}\text { 2. Selected bond } \\
\left.\mathrm{H}_{2} \mathrm{O} \mathrm{O}_{2}\right]_{\mathrm{n}} 2 \mathrm{H} \mathrm{H}_{2} \mathrm{O}(1)^{-740}\end{array}$ & lengths/ $A^{\circ}$ & compound \\
\hline $\mathrm{Cu}(1)-\mathrm{N}(1)$ & $19480(14)$ & $O(3)-H(31)$ & $0.847(5)$ \\
\hline $\mathrm{Cu}(1)-\mathrm{O}(1)$ & $19612(11)$ & $O(3)-H(32)$ & $0.848(5)$ \\
\hline$C u(1)-O(3)$ & $19675 / 11)$ & $O(4)-H(41)$ & $0.849(5)$ \\
\hline $\mathrm{Cu}(1)-\mathrm{N}(2)$ & $19989(14)$ & $\mathrm{O}(4)-\mathrm{H}(42)$ & $0.849(5)$ \\
\hline$C u(1)-S(1)$ & $2882 / 6]$ & $O(5)-H(51)$ & $0.847(5)$ \\
\hline$c(1)-S(1)$ & $16375 / 16)$ & $\mathrm{O}(5)-\mathrm{H}(52)$ & $0.847(5)$ \\
\hline$N(2)-C(2)$ & $1338(2)$ & $0(6)-H(61)$ & $0.847(5)$ \\
\hline $\mathrm{N}(2)-\mathrm{C}(6)$ & $1352(2)$ & $0(6)-H(62)$ & $0.847(5)$ \\
\hline
\end{tabular}

Symmetry code: ${ }^{\mathrm{x}} 1 / 2-x_{\mathrm{r}}-112+x, z^{\mathrm{b}} 1 / 2-x_{,}, 112+x, z-$

$c_{1 / 2-x} 112+y, z_{*}{ }^{d} 1 / 2+x, 1 / 2-x_{n}-z$

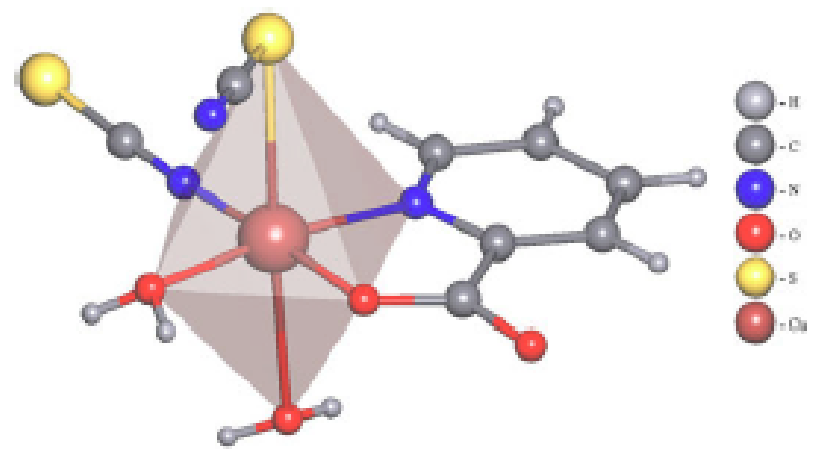

Figure 3. Coordinaton around $\mathrm{Cu}^{+2}$ cations in $\left[\mathrm{Cu}\left([)(\mathrm{SON}) \mathrm{H}_{2} \mathrm{O}\right)_{2}\right]_{n} 2 \mathrm{H}_{2} \mathrm{O}(1)$.

acoustic cavitation: the formation, growth, and implosive collapse of bubbles in a liquid. The collapse of these bubbles is an almost adiabatic process, thereby resulting in the massive build-up of energy inside the bubble, resulting in extremely high temperatures and pressures in a microscopic region of the sonicated liquid. The high temperatures and pressures result in the chemical excitation of any matter that was inside of, or in the immediate surroundings of the 
bubble as it rapidly imploded. A broad variety of outcomes can result from acoustic cavitation, including sonoluminescence, increased chemical activity in the solution due to the formation of primary and secondary radical reactions, and increase chemical activity through the formation of new, relatively stable chemical species that can diffuse further into the solution to create chemical effects (e.g. the formation of hydrogen peroxide from the combination of two hydroxyl radicals formed following the dissociation of water vapor inside the collapsing bubbles what water is exposed to ultrasound (Figure 2). In generally, sonochemistry method is fast method in compared to solvothermal, hydrothermal, branched tube, solvent diffusion, etc methods. ${ }^{[59,60]}$

Three nanostructures of $\left[\mathrm{Cu}(\mathrm{L})(\mathrm{SCN})\left(\mathrm{H}_{2} \mathrm{O}\right)_{2}\right]_{\mathrm{n}} \cdot 2 \mathrm{H}_{2} \mathrm{O}$ (1) were prepared by sonochemical process. Firstly, a high-density ultrasonic probe was immersed directly into the solution of $\mathrm{Cu}\left(\mathrm{NO}_{3}\right)_{2} .2 .5 \mathrm{H}_{2} \mathrm{O}(10 \mathrm{ml}, 0.05 \mathrm{M})$ in water. Then into this solution, a proper volume of $\mathrm{KSCN}(10 \mathrm{ml}, 0.05 \mathrm{M})$ and 2-pyridinecarboxylic acid (L) $(10 \mathrm{ml}, 0.05 \mathrm{M})$ ligand in water solvent was added in a drop wise manner. The

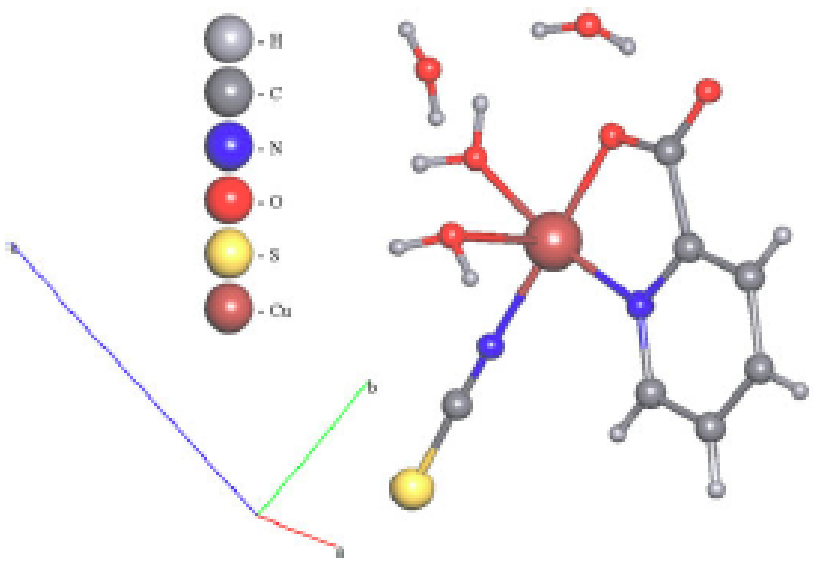

Figure 4. Asymmetric unit of compound of $\left[\mathrm{Cu}\left(\mathrm{L}(\mathrm{SCCN}) \mathrm{H}_{2} \mathrm{O}_{2}\right]_{n} 2 \mathrm{H}_{2} \mathrm{O}\right.$ (1). solution was irradiated by ultrasound at $60 \mathrm{~W}$ and temperature $30{ }^{\circ} \mathrm{C}$. After $30 \mathrm{~min}$, a white powder was obtained (temperature: $30{ }^{\circ} \mathrm{C}$ reaction time. $30 \mathrm{~min}$, sonication power: $60 \mathrm{~W}$, concentration: $0.05 \mathrm{M}$ ). Following the above process, the role of temperature and time reaction was studied. Firstly, for the study of the effect related with the temperature, the reaction described was carried out at $60^{\circ} \mathrm{C}$ (reaction time: $30 \mathrm{~min}$, sonication power: $60 \mathrm{~W}$, concentration: $0.05 \mathrm{M}$ ). The reaction time was increased up to $60 \mathrm{~min}$ (temperature: $30^{\circ} \mathrm{C}$, sonication power: $60 \mathrm{~W}$, concentration: $0.05 \mathrm{M}$ ). Finally, the concentration of reactants was investigated to $0.1 \mathrm{M}$ (temperature: $30^{\circ} \mathrm{C}$, sonication power: 60 $\mathrm{W}$, reaction time: $30 \mathrm{~min}$ ). In all the cases, the obtained precipitates were filtered, subsequently washed with water and then dried.

Compound 1: $(0.162 \mathrm{~g}, 51.42 \%$ yield based on final product), product 1: m.p $>300{ }^{\circ} \mathrm{C}$. Anal. Calc. for $\mathrm{C}_{7} \mathrm{CuH}_{12} \mathrm{~N}_{2} \mathrm{O}_{6} \mathrm{~S}: \mathrm{C}: 26.59 \%, \mathrm{H}: 3.79 \%$, N: $8.87 \%, \mathrm{O}: 30.39 \%$ Found $\mathrm{C}: 26.54 \%, \mathrm{H}: 3.54 \%, \mathrm{~N}: 8.73 \%, \mathrm{O}: 30.32 \%$. IR

Table 3. Selected bond lengths ( $A$ and angles $\rho^{\rho}$ ) in coppert. (1) coordinafon compounds.

\begin{tabular}{|c|c|c|c|}
\hline Compounds & $\mathrm{Cu}-\mathrm{N}$ & $\mathrm{Cu}-5$ & Ref. \\
\hline$\overline{\mathrm{Cu}}\left(\mathrm{U}(\mathrm{SCN})\left(\mathrm{H}_{2} \mathrm{O}\right)_{2} \mathrm{~h}_{2} 2 \mathrm{H}_{2} \mathrm{O}\right.$ & $1948(14)$ & $2882(6)$ & This wo: \\
\hline 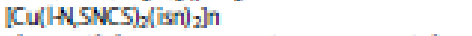 & $1950(1)$ & $2949(4)$ & [75] \\
\hline$\left[\left\{\left(\mathrm{Cu}_{2} \mathrm{~L}_{2}\right)\right\}\left\{\mathrm{Cul} / \alpha_{1} r-1,3-\mathrm{SON}\right),\left(\mu-1,1,3-\mathrm{CCN}_{4}\right\}\right]_{n}$ & $2007(2)$ & $2713(2)$ & [76] \\
\hline$\left[\left\{\left(\mathrm{Cu}_{2} \mathrm{~L}_{2}\right)\right\}\left\{\mathrm{Cu} /(\mu-1,3-\mathrm{SON}),(\mu 1,1,3-\mathrm{SON})_{2}\right\}\right\}_{h}$ & $2020(3)$ & $2720(1)$ & [76] \\
\hline$\left[\mathrm{Cu}(4 \mathrm{~B} p \mathrm{py})_{2}(\mathrm{NCS})_{2}\right]$ & $1958 / 8)$ & $3.078(10)$ & [77] \\
\hline $\left.\mathrm{KCu}(4-\mathrm{pic})_{2}(\mathrm{NCS})_{2}\right]$ & $2003 / 8)$ & $3.109(4)$ & [78] \\
\hline isf $\left\{\mathrm{Cu}(\mathrm{SON})_{2}(\mathrm{bop} y)_{2}\right]$ & $2009(4)$ & - & [79] \\
\hline tans-[Cu (SON $)_{2}$ (bopy) $\left.)_{2}\right]$ & $1965[14]$ & - & [79] \\
\hline $\left.\mathrm{KuKCl}_{2} / \mathrm{bop} \mathrm{d}_{2}\right]$ & $2006(17)$ & - & [79] \\
\hline$\left.\left[\mathrm{Cu}(\mathrm{NCS})_{2} \text { (pyrimidine }\right)_{2}\right]_{n}$ & $2040(2)$ & $2808(10)$ & 180] \\
\hline$\left[\mathrm{Cu} / \mathrm{SON}(3-\mathrm{Aqpy})_{2}\right]_{n}$ & $2072(5)$ & $2479(7)$ & [81] \\
\hline$\left.\left[\mathrm{Cu}_{2} / \mathrm{SON}_{4} / 3-\mathrm{Acpy}\right)_{4}\right]$ & $2048(2)$ & $2863(1)$ & [B1] \\
\hline$\left[\mathrm{Cu}_{2}(\mu \text {-dea })_{2}(\mathrm{NCS})_{2}\right]$ & $1926(17)$ & - & [182] \\
\hline$\left(\mathrm{Cu}_{2}(\mathrm{taec})(\mathrm{NCS})_{2} \mathrm{YOO}_{4}\right)_{2}, \mathrm{H}_{2} \mathrm{O}$ & $2085(5)$ & - & 183] \\
\hline$\left.[\mathrm{Cu} / 4 \mathrm{epy})(5 \mathrm{CN})_{2}\right]_{n}$ & $2023(2)$ & $2867(1)$ & 184] \\
\hline $\mathrm{KCu} / 2 \mathrm{ambaim}) \mathrm{SSCN}_{2} \mathrm{~h}_{\mathrm{h}}$ & $1975 / 3)$ & $2952(13)$ & 184] \\
\hline 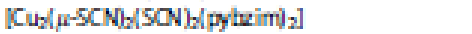 & $1970,2)$ & $2942(8)$ & [84] \\
\hline $\mathrm{Cu} / \mathrm{SON}_{2}\left\{(\mathrm{py})_{2} \mathrm{COEE}(\mathrm{OH})\right\}_{2}, 2 \mathrm{EtOH}$ & $2033(16)$ & $2925(9)$ & 185] \\
\hline
\end{tabular}

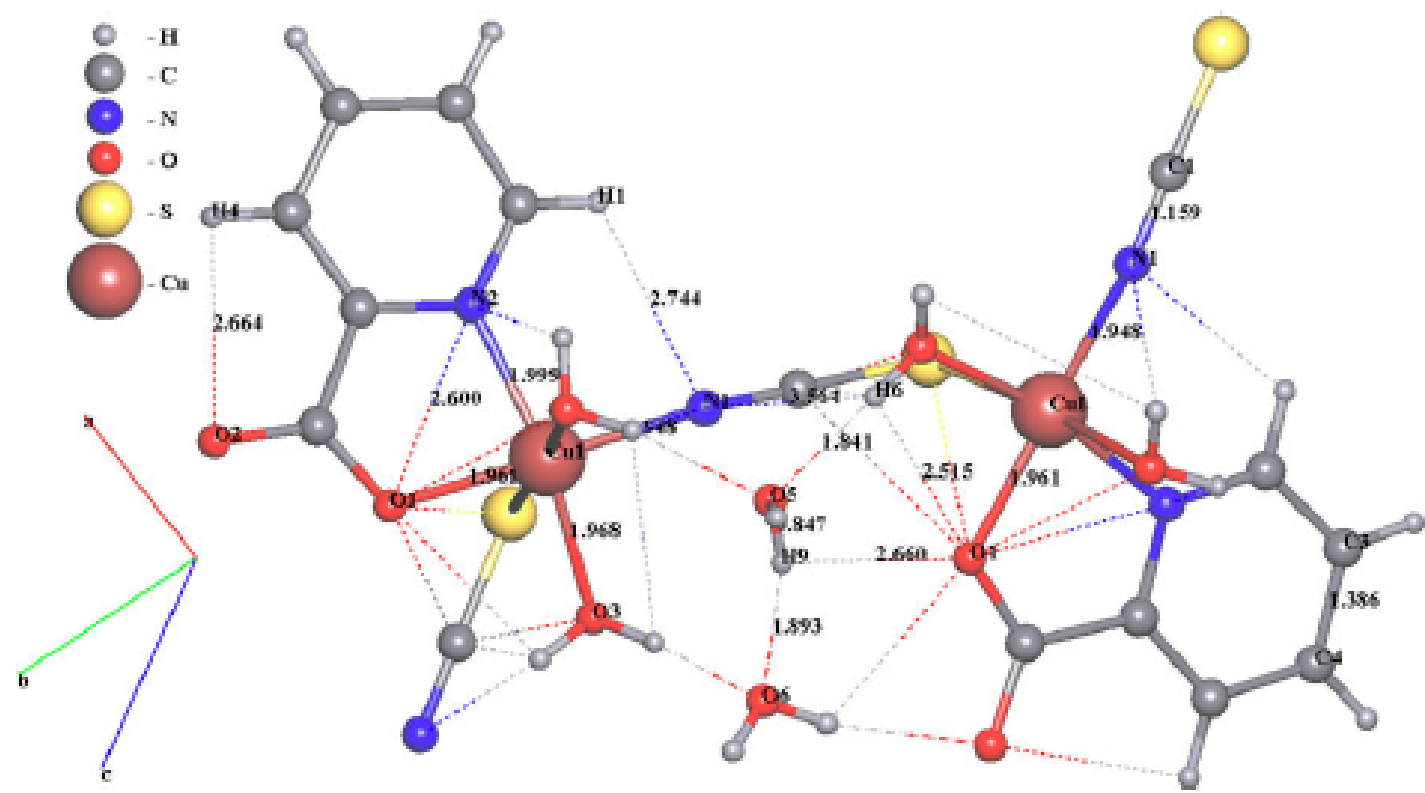

Figure 5. Selected distances for compound $\mathrm{KCu}(\mathrm{L} / \mathrm{SCN}) \mathrm{H}_{2} \mathrm{O}_{2} \mathrm{~h}_{2} 2 \mathrm{H}_{2} \mathrm{O}$ (1). 


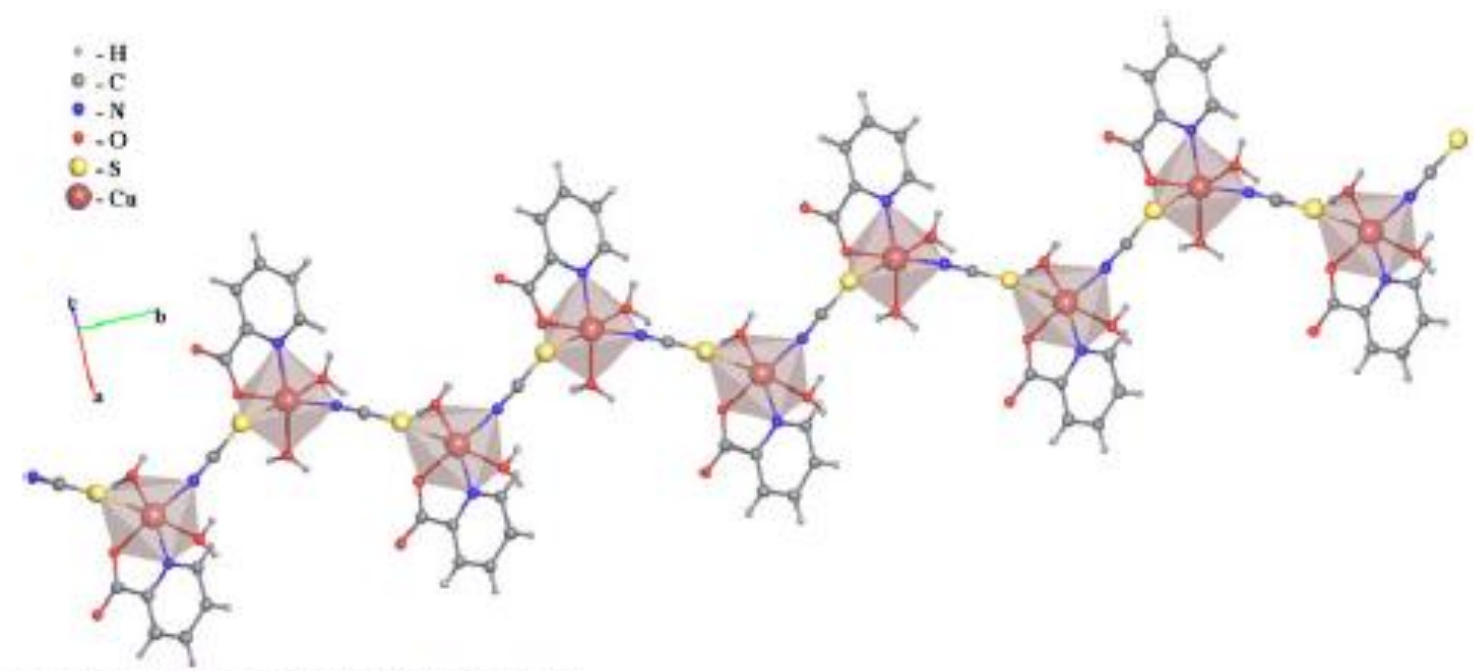

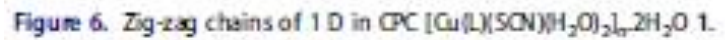

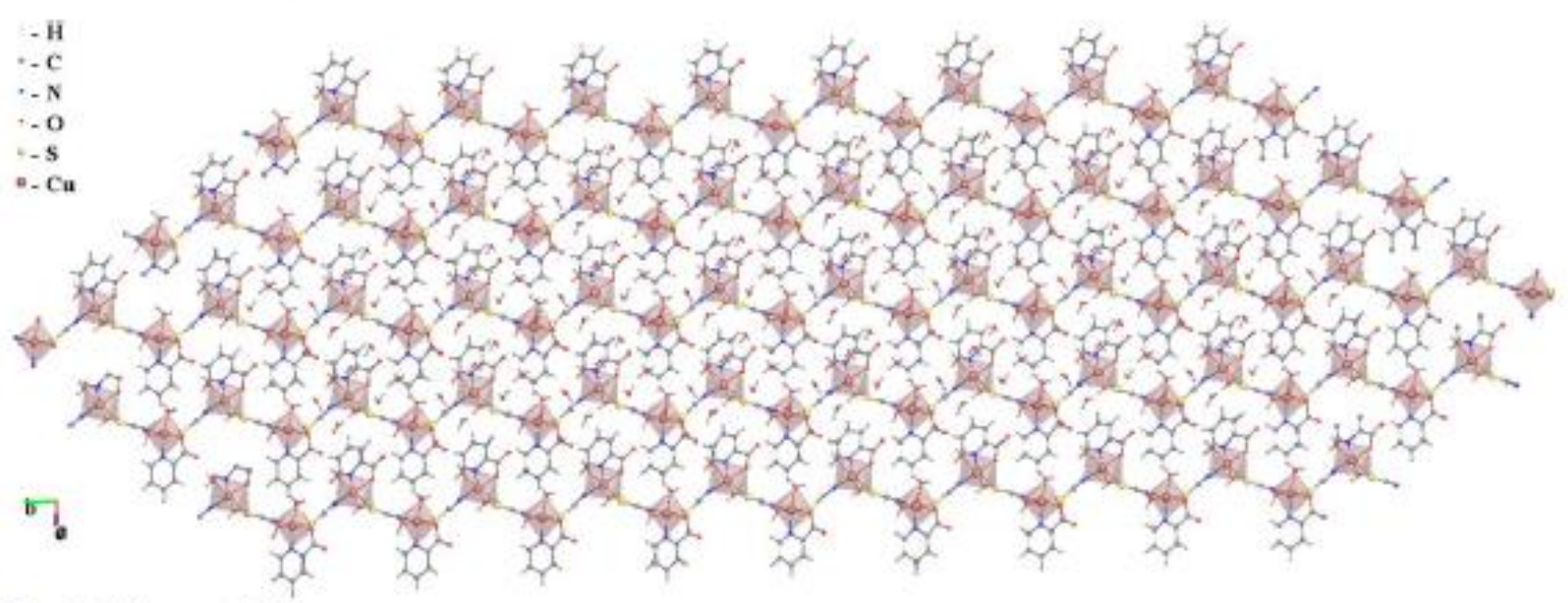

Figure 7. 20 tragments of 1 .

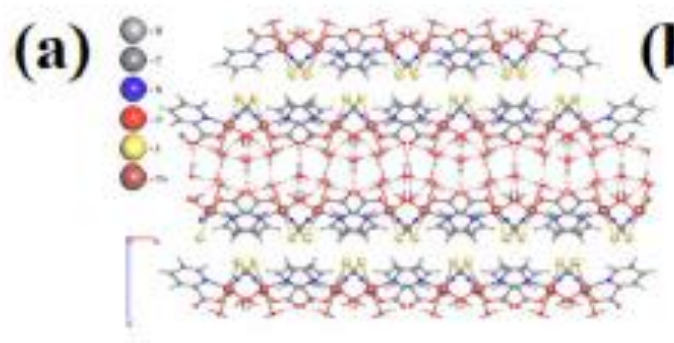

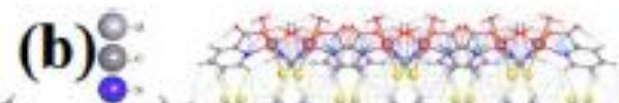
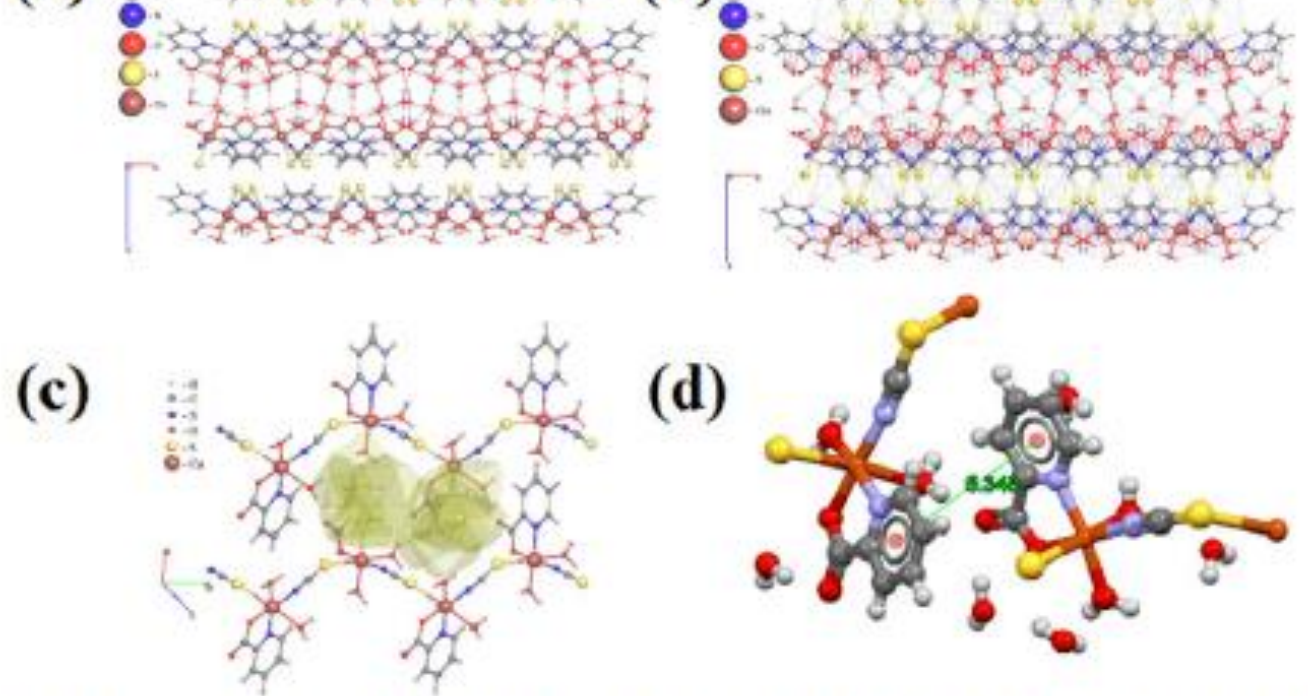

(d)

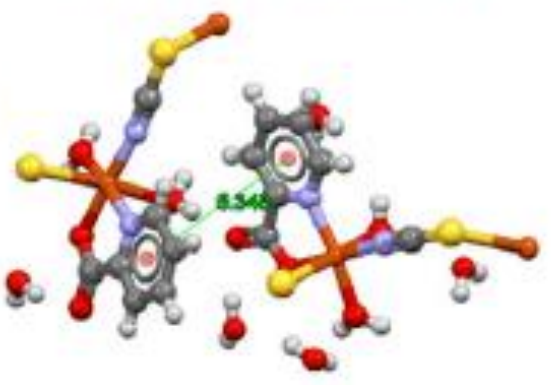

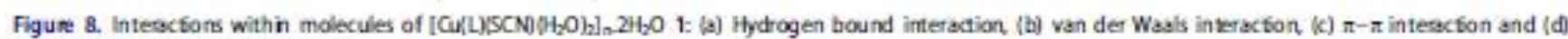
distance of aromafic rings (bottom). 

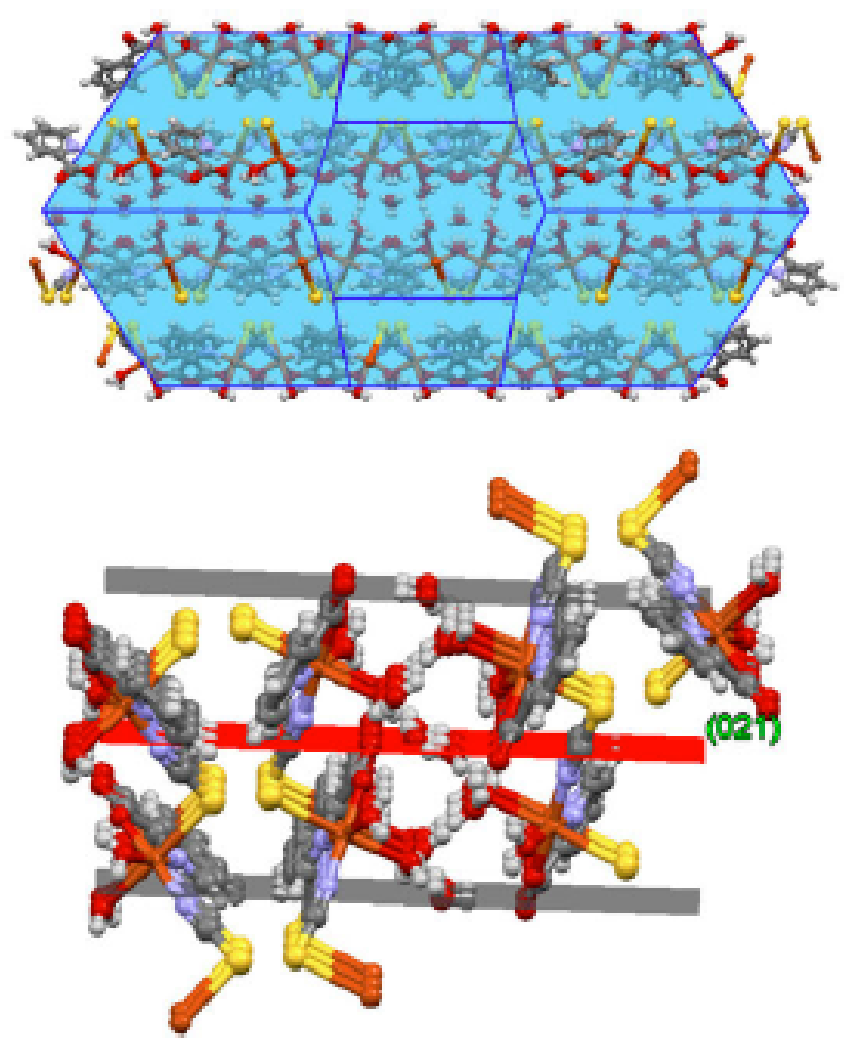

Figure 9. Predicted crystal morphologies of $\mathrm{KCu} / \mathrm{L})(\mathrm{SCN}) \mathrm{H}_{2} \mathrm{O}_{2} \mathrm{~h}_{7} 2 \mathrm{H}_{2} \mathrm{O} 1$ (up) and their padking along the 1010$]$ for $\left(\mathrm{Cu} / \mathrm{U}(\mathrm{SCN}) / \mathrm{H}_{2} \mathrm{O}\right)_{2} \mathrm{l}_{2}-2 \mathrm{H}_{2} \mathrm{O} 1$ (down).

(selected bands for compound 1 ; in $\mathrm{cm}^{-1}$ : 3440(b), 3079(w), $1647(\mathrm{~s}), 1605(\mathrm{~s}), 1348(\mathrm{~s}), 778(\mathrm{~s}) \mathrm{cm}^{-1}$.

\section{Results and discussion}

Initially, compound $\mathbf{1}$ was synthesized by the branch tube method. For the synthesis of compound $1, \mathrm{Cu}\left(\mathrm{NO}_{3}\right)_{2}$ $.2 .5 \mathrm{H}_{2} \mathrm{O}, 2$-pyridinecarboxylic acid (L) and $\mathrm{KSCN}$ were loaded into one arm of a branch tube while filling both arms slowly with water. The chemical bearing arm was afterwards immersed in an oil bath kept at $60^{\circ} \mathrm{C}$ while the second remains at room temperature. After 5 days, colorless crystals were deposited in the cooler arm. The crystals obtained were filtered off, washed with water, air dried and finally characterized as compound $\mathbf{I}$ (vide infra).

\section{$X$-ray characterization}

Selected crystals of compound $\mathbf{I}$ was isolated and analyzed by X-ray diffraction, crystallizing both in an orthorhombic Pbca space group. For more crystallographic details see Tables 1 and 2 .

Compound $\mathbf{1}$. The $\mathrm{Pb}$ atoms of $\mathbf{1}$ are coordinated by two $\mathrm{N}$ atoms, three $\mathrm{O}$ atoms and one $\mathrm{S}$ atom composing octahedral coordination $\mathrm{O}_{3} \mathrm{~N}_{2} \mathrm{~S}$ (Figure 3). The asymmetric unit of compound $\mathbf{I}$ contain one $\mathrm{Cu}^{2+}$ cation, which is coordinated to one 2-pyridinecarboxylic acid ligand $\left(\mathrm{L}=\mathrm{C}_{6} \mathrm{H}_{5} \mathrm{NO}_{2}\right)$, one $\mathrm{SCN}^{-}$anions and two $\mathrm{H}_{2} \mathrm{O}$ molecules which are in crystal lattice (Figure 4). Each 2-pyridinecarboxylic acid ligand $\left(\mathrm{L}=\mathrm{C}_{6} \mathrm{H}_{5} \mathrm{NO}_{2}\right.$ ) in compound $\mathbf{I}$ is coordinated to one $\mathrm{Cu}$ atom by one $\mathrm{N}$ atom of pyridine ring $(\mathrm{Cu}-\mathrm{N}$ distance 2.343 A) and one $\mathrm{O}$ atoms of carboxylic acid group ( $\mathrm{Cu}-\mathrm{O}$ distance $1.96 \AA$ ). Additionally, one bridge $\mathrm{SCN}$ atoms are coordinated to two $\mathrm{Cu}$ atoms through $\mathrm{Cu}(1)-\mathrm{Nl}$ and $\mathrm{Cu}(1)-\mathrm{S} 1$ bounds ( $\mathrm{Cu}-\mathrm{N}$ and $\mathrm{Cu}-\mathrm{S}$ distances are 1.948 and $2.882 \AA$, respectively; Table 2 and Figure 5). The length of $\mathrm{Cu}-\mathrm{N}$ and $\mathrm{Cu}-\mathrm{S}$ bonds are shown for some of coordination supramolecular compounds based on copper metal in Table 3. It should be noted that the coordination interactions can be separated in two groups: strong (more valence, in short range $0.845-2.520 \mathrm{~A}$ ) and weak (more electrostatic, in long range 2.664-3.570 A). Strong bonds form mononudear compounds $\left[\mathrm{Cu}(\mathrm{L})(\mathrm{SCN})\left(\mathrm{H}_{2} \mathrm{O}\right)_{2}\right]$, which expanded by relatively weak interactions in polymeric layer $\left[\mathrm{Cu}(\mathrm{L})(\mathrm{SCN})\left(\mathrm{H}_{2} \mathrm{O}\right)_{2}\right] .2 \mathrm{H}_{2} \mathrm{O}$. Also structures of compound 1 are two-periodic $([1,1,0]$ orientation) and one-periodic (in $[0,1,0]$ direction) coordination polymer architectures (Figures 6 and 7). Each isothiocyanate groups is linking two similar copper atoms. These 1D zig-zag chains are bridged by the isothiocyanate groups through forming and expanded by hydrogen bound, $\pi-\pi$ stacking and van der Waals interactions a layer on the $a b$ crystal plane (Figures 6, 8, and 9). It should be noted that additional weak $\pi-\pi$ interaction reinforces CPC. The $\pi-\pi$ interactions in 1 , are due to the presence of the rings of pyridine (distance of two pyridine rings: $5.348 \AA$ ) allowing the interactions between the parallel chains (Figures 8 and 9).

The morphology and size of products prepared by the sonochemical method were examined by SEM, (Figure 10). The SEM micrographs of compound 1 show plate morphology. Bravais Friedel Donnay Harker (BFDH) analysis was carried out in order to estimate the faces that are supposed to appear in the crystals morphology (Figure 9). This analysis considers the effect of symmetry operations on the interplanar distances of crystal faces. ${ }^{(63)}$ Predicted crystal morphologies of compound $\mathbf{1}$ are shown in Figure 11. In almost all cases there is a good match between the predicted and observed morphology. It should be noted that in the case of 1 , the growth of the coordination material takes place along the [021] directions (Figure 9).

Each $\left[\mathrm{Cu}(\mathrm{L})(\mathrm{SCN})\left(\mathrm{H}_{2} \mathrm{O}\right)_{2}\right]_{\mathrm{n}} \cdot 2 \mathrm{H}_{2} \mathrm{O}$ chain is located between six other same chains forming van-der-Waals hydrogen bonded and $\pi-\pi$ interactions hexagonal packing, which corresponds to geometrically octahedral packing (Figures 9 and 12). Simplification of the chain to the underlying net by ToposPro package reveals $2 \mathrm{Cl}$ topological type (Figure 13), which is abundant for ID coordination polymers $(56,607$ examples in TTO collection of ToposePro). ${ }^{|6,-62|}$

\section{Hirshfeld surface analysis}

The crystal structure from the title compound as discussed below is a good example of the interplay of different molecular interactions. In order to analyses the various interactions that lead to the crystal structure, an intermolecular intercontacts leading to the Hirshfeld surfaces has 

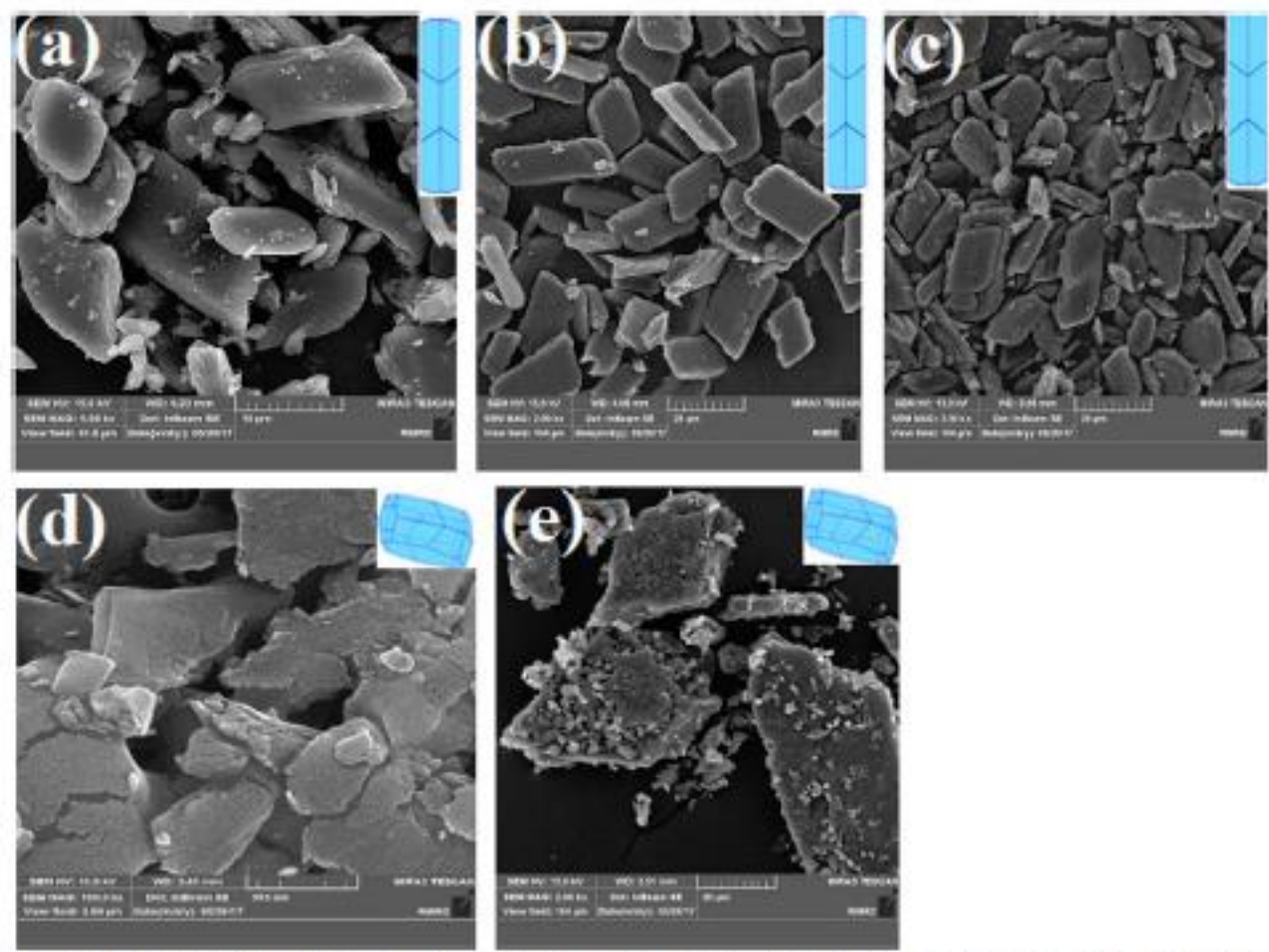

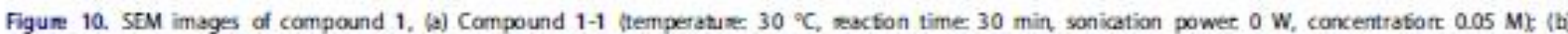

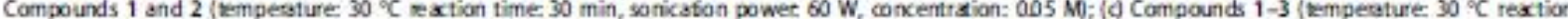

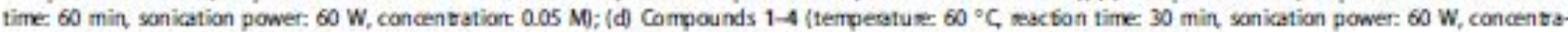
tion: $0.05 \mathrm{M}$ ) (e) (d) Compounds $1-5$ (temperatuse $30^{\circ} \mathrm{C}$, nextion time: 30 min, saniation powet $60 \mathrm{~W}$, concentotion: $0.1 \mathrm{M}$ ).

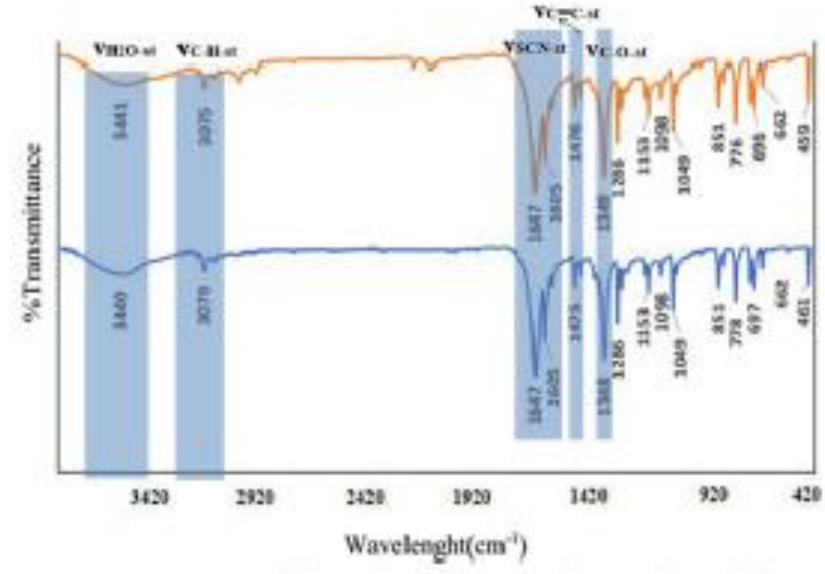

Figun 11. FTH specte of (brown line) buik materials as symthesized of compound 1 and (bive ine) nano-siaed compound 1 prepared by sonochemical method.

been made. The Hirshfeld surface considered the volume of space where molecule electron density exceeds that all neighboring molecules. ${ }^{[6,-\infty]}$ Molecular Hirshfeld surfaces have been constructed from CIF file, so that you can dissect crystal structures into noncovalent contacts The very highresolution Hirshfeld surfaces were generated by Crystal Explorer and functions of curvature, distance including shape index and dnorm were mapped to the surfaces. ${ }^{|6-77|}$ The function dnorm is a normalized distance property

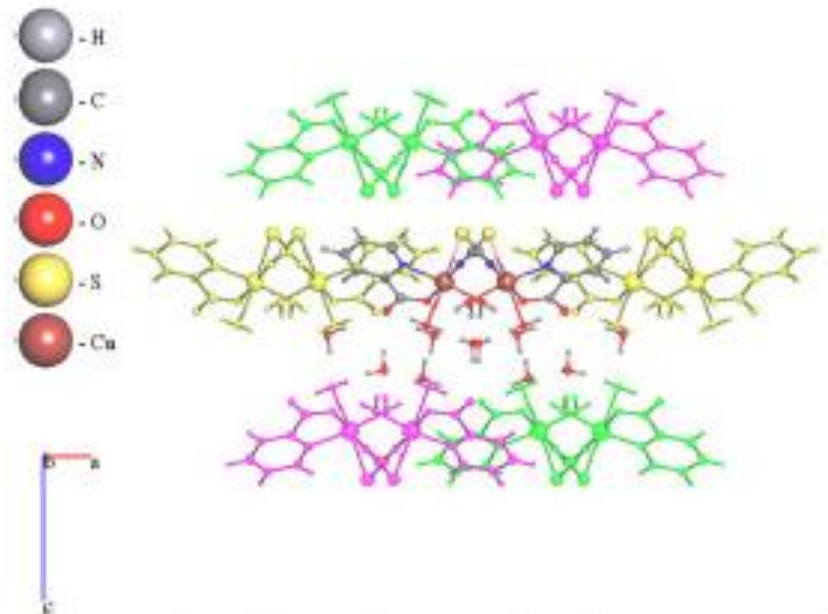

Figun 12. Number of chains, dhains surnounding the consftutive unit of

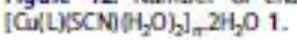

defined with regards to $d_{i}$ (distance from a point on the Hirshfeld surface to the nearest internal nudeus), $d_{c}$ (distance from a point on the Hirshfeld surface to the nearest external nucleus) and van der Waals radii ( $r_{i}^{\text {dvw }}$ and $\left.r_{e}{ }^{d v w}\right)$ : $d_{\text {norm }}=\left[\left(d_{i}-r_{i}{ }^{d v W}\right) / r_{i}{ }^{d v W}\right]+\left[\left(d_{c}-r_{e}{ }^{d v W}\right) / r_{c}{ }^{d v W}\right] .^{|22-24|}$ Thus, the value of $d_{\text {nom }}$ was negative or positive when intermolecular contacts were shorter or longer than $r^{\text {vdw }}$, respectively. The Hirshfeld surfaces of the title compound 
(a)

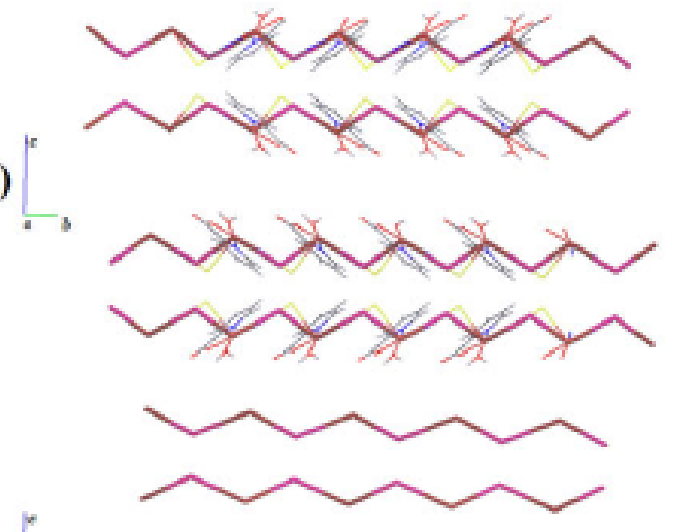

(b)

(c)

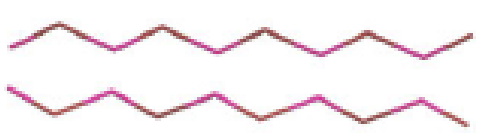

8.
$8 . \mathrm{c}$
. $\mathrm{x}$
. $\mathrm{s}$
$9 . \mathrm{v}$
$9 . \mathrm{cu}$

Figure 13. (a): The 10 chain of $1 \mathrm{~s}$ formed by Cu(II), Land SCNibs abng crystalographic ' $b$ axis (b): Simplified network of 1 . ( $\mathrm{d}$ : The building bloods of network 1.
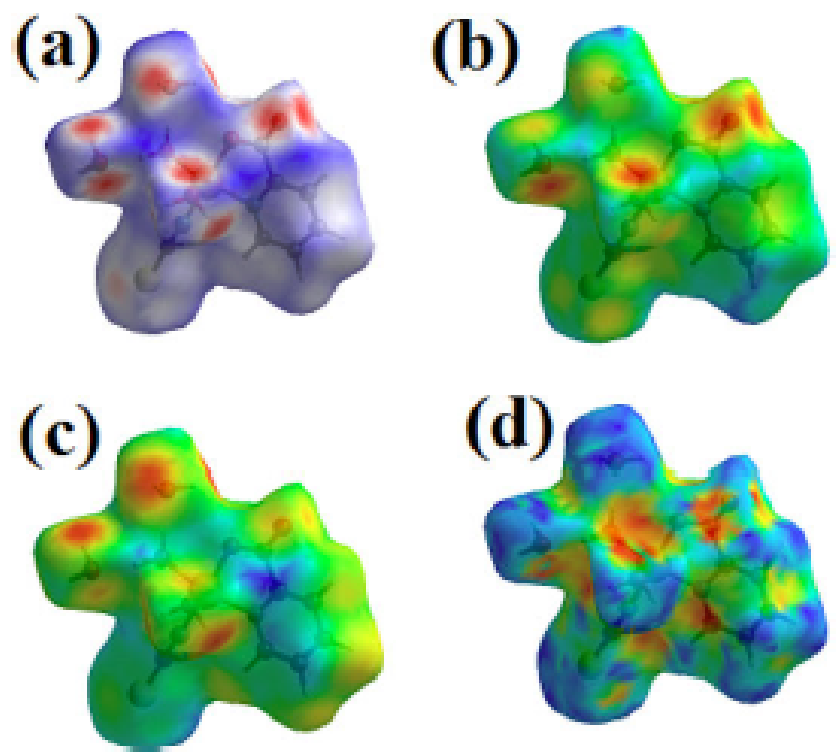

Figure 14. Hishteld surface analysis of $1:(a) d_{\text {nomr }}$ (b) $d_{c}\left(\right.$ c) $d_{p}$ (d) shape-index.

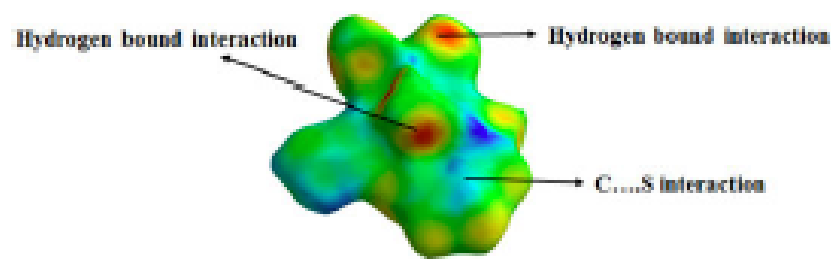

Figun 15. Hirshfeld sufaces of 1 surface index.
(Figure 14) were mapped over a $d_{\text {norm }}, d_{e}, d_{i}$, curvedness, and shape-index.

The $d_{\text {norm }}$ values were mapped to the Hirshfeld surface (Figure 14(a)) by using a red-blue-white color scheme as follows: red regions represented closer contacts as well as a negative dnorm value; blue regions represented longer contacts and a positive dnorm value; and white regions represented the distance of contacts equal to precisely the van der Waals separation with a $d_{\text {norm }}$ value of zero. These normalized contact distances $\left(d_{\text {norm }}\right)$ reveal the dose contacts of hydrogen bond donors and acceptors, but other dose contacts are evident. Actually, Figure 12(a) reveals that the large circular depressions are the indicators of hydrogen bonding contacts and the dominant interactions are $\mathrm{O}-\mathrm{H}$ whereas other visible spots are due to $\mathrm{H}-\mathrm{H}$ contacts, based on both $d_{e}$ and $d_{\mathrm{i}}$. Particularly, adjacent red/orange and blue triangle like patches on a shape index map (Figure 15) give us information about hydrogen bound and C...S interaction. ${ }^{\mid 66,69-73]}$ The combination of the distances from the Hirshfeld surface to the nearest nudeus inside the surface $\left(d_{i}\right)$ and outside the surface $\left(d_{e}\right)$ and the data conveyed by the shape index are consistent with $2 \mathrm{D}$ fingerprint plots. ${ }^{[64,-5]}$

The $2 \mathrm{D}$ fingerprint maps of $\mathbf{1}$ provide some quantitative information gives the possibility of obtaining additional insight to the intermolecular interactions in the crystal state and for describing the surface characteristics of the molecules (Figure 16). Globally, H..... H, H ...... O, C......H, and $\mathrm{S} \ldots . \mathrm{H}$ intermolecular interactions were most abundant in the crystal packing $(29.8 \%, 24.6 \%, 14.1 \%$, and $11.4 \%$, respectively). It really is evident that van der Waals forces exert an important influence on the stabilization of the packing in the crystal structure, and other intercontacts $[\mathrm{N} \ldots \ldots \mathrm{H} / \mathrm{H} \ldots \ldots \mathrm{N} \quad(4.0 \%), \mathrm{C} \ldots . \mathrm{O} \quad(4.0 \%), \quad \mathrm{C} \ldots \ldots \mathrm{S}$ (3.7\%), N..... (2.5\%), and H..... Cu (0.1\%)] contribute less to the Hirshfeld surfaces. On the other hand, the relative contributions of the different interactions to the Hirshfeld Surfaces were also calculated for the title compound (Figure 17 and Table 4).

\section{Sonochemical synthesis}

Synthesis of compound $\mathbf{1}$ was alternatively achieved by the application of ultrasounds. For the synthesis of compound 1, a high-density ultrasonic probe was immersed directly into a water solution $\mathrm{Cu}\left(\mathrm{NO}_{3}\right)_{2} 2.5 \mathrm{H}_{2} \mathrm{O}$ and posterior drop wise addition a second water solution of KSCN and 2-pyridinecarboxylic acid (L). The synthesis were done the reactants concentration and the ultrasound power while other factors such as temperature and the reaction time were systematically modified (a resume of the different reactions is shown in Table 5).

PXRD of compounds is similar to that obtained upon simulation from the X-ray diffraction data obtained for $\mathbf{1}$. As Figure 18 reveals that both (experimental and simulation) exhibit the same crystalline phase. These results indicate the existence of a single crystalline phase, which is maintained independently of the synthesis method (Figure 10). 

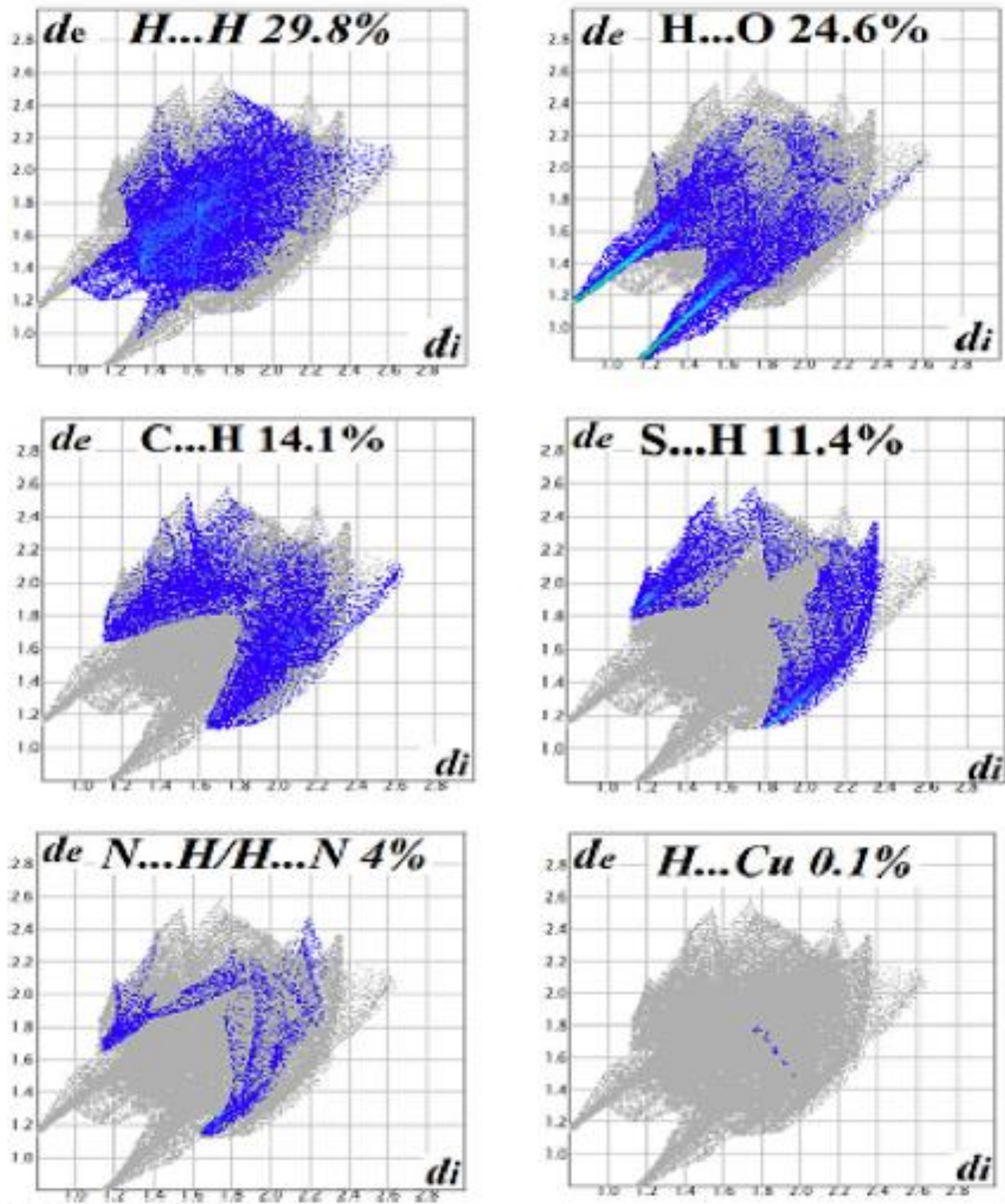

Figure 16. Fingerpint plats of mejor comtads in 1 .

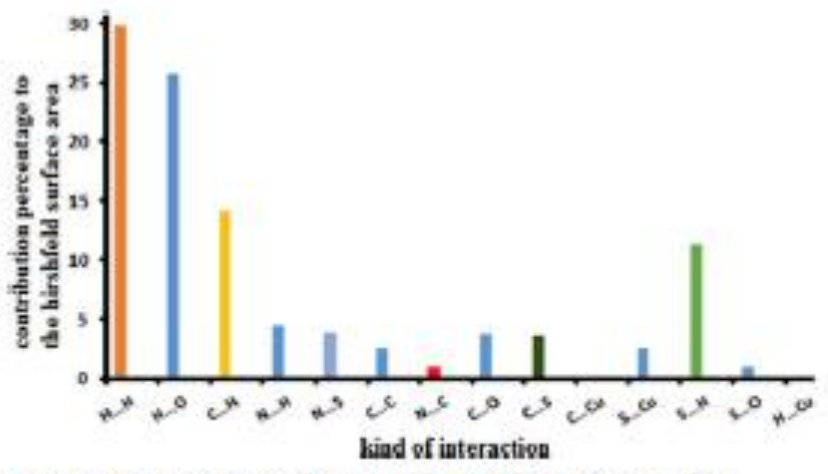

Figune 17. The relafive contributions to the Hrshteld sufface aned far 1.

Various conditions for preparation of compounds $\mathbf{I}$ nano-structure were summarized in Table 5. In this table, sample 1-1, were studied without power ultrasound and the other samples were studied under variable temperature, time

and power ultrasound. In order to research the role of power ultrasound irradiation on the character of product, reactions were performed under completely different power ultrasound irradiation. Results show a decrease in the particles size as increasing power ultrasound irradiation. In sample 1-1, the reactions were studied without power ultrasound. Results show that size partides sample of 1-1 (Figure $10(\mathrm{a})$ ) is larger than 1-2 (Figure 10(b)). Table 5 shows the average diameter scanning electron micrographs (SEM) of the prepared samples. Results show high power ultrasound irradiation decreased agglomeration, and thus led to decrease particles size. Comparison between samples 1-2 and 1-3 shows a decrease in nanoparticle size. Thus, size particles of sample 1-3 are smaller than 1-2 (Figure $10(c)$ ). However, a reducing the reaction time led to the decrease of size particles of sample 1-3. Partide sizes and morphology of nanopartide are depending on temperature. Higher temperature $\left(60^{\circ} \mathrm{C}\right)$ results in an increased solubility, and thus 
Table 4. Contribution to hishfeld surface area of dfferent inteaction in compounds 1.

\begin{tabular}{|c|c|c|c|}
\hline Interactions & Contribution to hishfeld surface anea (9) & Interactions & Comtribution to hirshfeld sufface area (9) \\
\hline $\mathrm{Cu} \ldots \mathrm{C}$ & 0.1 & N...S & 25 \\
\hline $\mathrm{Cu} \ldots \mathrm{S}$ & 26 & $5 \ldots .5$ & 3.7 \\
\hline $\mathrm{Cu} \ldots \mathrm{H}$ & a.1 & $5 \ldots .0$ & 0.9 \\
\hline C....C & 1.1 & H...N & 4.1 \\
\hline C...s & 3.7 & H... ᄃ & 14.1 \\
\hline C....H & 14.1 & H...S & 11.4 \\
\hline H....C & 14.1 & H...Cu & a.1 \\
\hline
\end{tabular}

Table 5. The infuence of ultrasound power, reaction time, temperature and concentration of reactants on the morphology of compounds 1 patide.

\begin{tabular}{|c|c|c|c|c|c|c|}
\hline Compound & $\mathrm{M}$ mol/D & $T\left({ }^{\circ} C^{b}\right.$ & $T$ iminf & Sonication ( $W$ ) & SEMP & Morphology \\
\hline $1-1$ & 0.05 & 30 & 30 & 0 & 548 & Mix mophology \\
\hline $\begin{array}{l}1-2 \\
1-3\end{array}$ & $\begin{array}{l}0.05 \\
0.05\end{array}$ & $\begin{array}{l}30 \\
30\end{array}$ & $\begin{array}{l}30 \\
60\end{array}$ & $\begin{array}{l}60 \\
60\end{array}$ & $\begin{array}{r}183 \\
92\end{array}$ & $\begin{array}{l}\text { Nano plate } \\
\text { Macro plate }\end{array}$ \\
\hline $1-4$ & 0.05 & 60 & 30 & 60 & 168 & Macro plate \\
\hline $1-5$ & 0.1 & 30 & 30 & 60 & 378 & Mix mophology \\
\hline
\end{tabular}

"Concentration of nital reactamt.

breaction tempesture.

"Peaction time.

${ }^{\mathrm{d}}$ Average dameter.

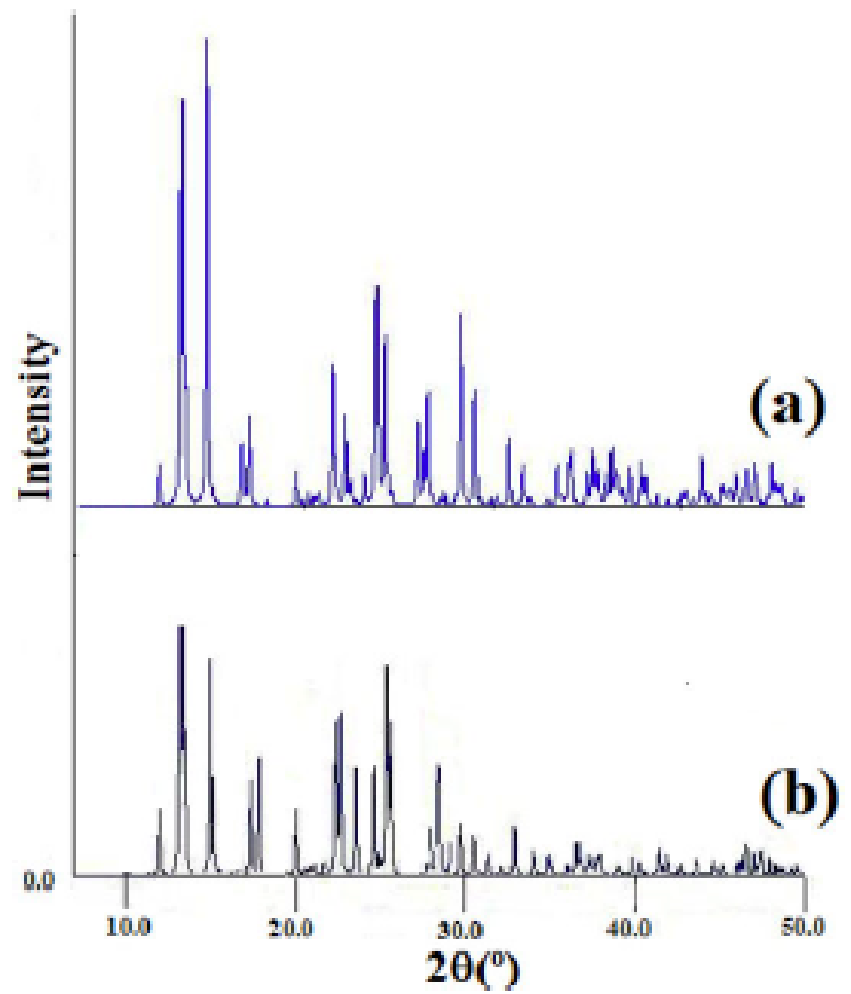

Figure 18. (a) PXRD pattems carnesponding to the simulation of single aystal $X$-ray data compound 1 and (b) cornesponding to the nano-structured systems 1.

a reduced supersaturation of growth species in the solution, and thus particles size of sample $1-4$ is smaller than particles size of sample 1-2 (Figure 10(b,d)). Finally, was compared 1-5 and 1-2 samples and shows an increase in partide size. In the other hand, high concentration of reactants increased agglomeration, and thus led to increase particles size (Figure $10(\mathrm{~b}, \mathrm{e})$ ). Table 5 shows the average

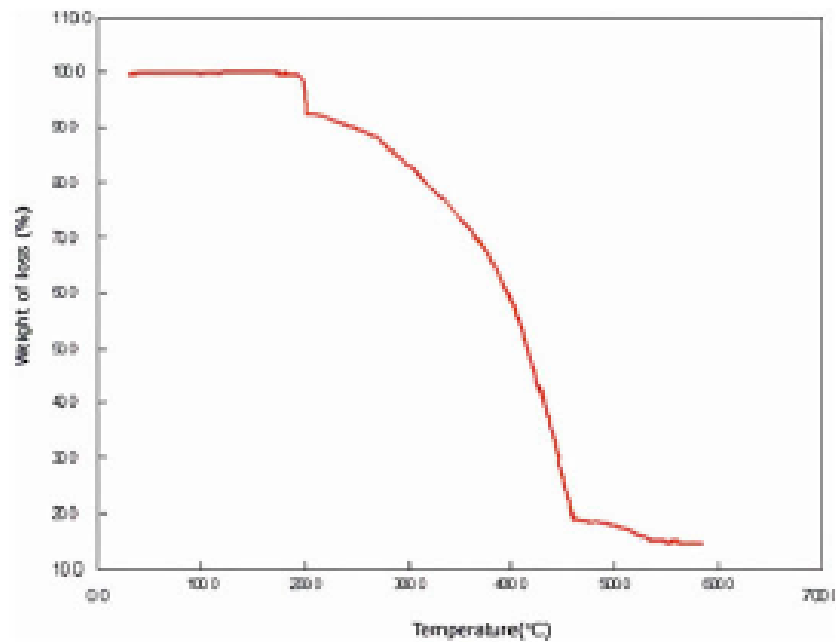

Figure 19. Thermal behavior of compound 1.

diameter of particles shown by SEM of the prepared samples. The best conditions for getting a small sized and less agglomerated nanostructure materials for this CPC are temperature, reaction time, the power of ultrasonic irradiation and concentration of reactants $30^{\circ} \mathrm{C}, 60 \mathrm{~min}, 60 \mathrm{~W}$, and $0.05 \mathrm{M}$, respectively. Also, other condition (temperature = $60^{\circ} \mathrm{C}$, reaction time $=30 \mathrm{~min}$, power of ultrasonic irradiation $=60 \mathrm{~W}$ and concentration of reactants $=0.05 \mathrm{M}$ ) is good for obtaining small nanoparticle size.

IR spectra of compound $\mathbf{1}$ shows the characteristic stretching frequency of $\mathrm{H}_{2} \mathrm{O}$ group observed at around 3474 $\mathrm{cm}^{-1}$, relatively weak absorption bands centered on 3000 $\mathrm{cm}^{-1}$ assigned to the $\mathrm{C}-\mathrm{H}$ stretching frequency of the aromatic rings. The absorption bands with variable intensity in the frequency range between 1700 and $1750 \mathrm{~cm}^{-1}$ correspond to $\mathrm{C}=\mathrm{O}$ stretching frequency of the carbonyl from the 2-pyridinecarboxylic acid ligand. Also, the characteristic band of the $\mathrm{C}-\mathrm{O}$ stretching frequency carboxylic acid group appeared between 1000 and $1300 \mathrm{~cm}^{-1}$. For the SCN ligand, a stretching band around $2050 \mathrm{~cm}^{-1}$ was assigned to $S C N$ group. In addition, two bands around $1500-1700 \mathrm{~cm}^{-1}$ revealed the presence of $\mathrm{C}=\mathrm{C}$ stretching frequency corresponding to the amine group of the ligand (Figure 11).

The TG curve of compound 1 indicates that the compound does melt and is stable up to $80{ }^{\circ} \mathrm{C}$ at that temperature it begins to decompose (Figure 8). A first weight loss over $50-100{ }^{\circ} \mathrm{C}$ corresponding to the loss of lattice water molecules. The decomposition of coordinated water (mass 
loss of $8.7 \%$ ), pyridine aromatic ring, carboxylate groups of 2-pyridinecarboxylic acid ligand and isothiocyanate groups (mass loss of them $77.4 \%$ ), occur in range of $110-470{ }^{\circ} \mathrm{C}$. Mass loss calculations show that the final decomposition product is $\mathrm{Cu}$ (Figure 19).

\section{Conclusion}

One $\mathrm{Cu}(\mathrm{II}) \quad \mathrm{CPC} \quad\left[\mathrm{Cu}(\mathrm{L})(\mathrm{SCN})\left(\mathrm{H}_{2} \mathrm{O}\right)_{2}\right]_{\mathrm{n}} \cdot 2 \mathrm{H}_{2} \mathrm{O} \quad$ (1) $\mathrm{L}=$ picolinic acid ligand, has been synthesized utilizing a thermal gradient approach and also by sonochemical irradiation. Compound $\mathbf{I}$ was structurally characterized by single crystal X-ray diffraction. The crystal structure of compound $\mathbf{I}$ is made up of $1 \mathrm{D}$ CPC and shows that the coordination number of $\mathrm{Cu}$ (II) ion in compound $\mathbf{I}$ is six. Also, topology, Hirshfeld surface analyses and thermal behavior were studied for $\mathbf{1}$. Influences of temperature, power ultrasound, reaction time and concentration of reactants on the morphological properties of $\left[\mathrm{Cu}(\mathrm{L})(\mathrm{SCN})\left(\mathrm{H}_{2} \mathrm{O}\right)_{2}\right]_{\mathrm{n}}, 2 \mathrm{H}_{2} \mathrm{O}$ (1), was studied. The results showed that higher temperature of reagents led to decrease in particle size and optimum time for the process was obtained $60 \mathrm{~min}$, increasing in the power of ultrasonic irradiation led to decrease partides size and high concentration of reactants increased agglomeration, and thus led to increase particles size for $\mathbf{1}$. Also, the best conditions for getting a small sized and less agglomerated nanostructure material for this coordination compounds are temperature, reaction time, the power of ultrasonic irradiation and concentration of reactants are $30{ }^{\circ} \mathrm{C}, 60 \mathrm{~min} 60$ $\mathrm{W}$, and $0.05 \mathrm{M}$, respectively. These results demonstrated that the use of ultrasounds and the correct selection of different parameters can led to the formation of expected morphologies then the project can be defined more dearly.

\section{Supplementary information}

Crystallographic data for the structure reported in this paper have been deposited with the Cambridge Crystallographic Data Center as supplementary publication no. CCDC1552099. Copies of the data can be obtained upon application to CCDC, 12 Union Road, Cambridge CB2 1EZ, UK (Fax: +44 1223/336033; e-mail: deposit@ccdc.cam.ac.uk).

\section{Acknowledgment}

Support of this investigation by University of Sistan and Baluchestan (USB) is gratefully aclanowledged. Payam Hayati would like to thanks Professor Davide.M.Proserpio (Milan, Italy) for teaching ToposPro les sons and Eugeny V. Alexandrov (Samara, Russia) for many fruitful dis cussions about coordination compounds topology.

\section{References}

[1] Beloglazkina, E; Majouga, A.; Moiseeva, A.; Yudin, L; Moiseev, F.; Shmatova, O.; Zyk N. Synthesis and Electrochemica Characterization of Complexes of 1, 2-bis [2-(pyridylmethylide. neamino) phenylthio] Ethanes with Transition Metals (CoII Nill, CuII). Russ Chem Buill 2008, 57,358-363. DOE 10.1007/ s11172-00s-0055-2
[2] Morshedi, M.; Amirnasr, M.; 'Triki, S.; Khalaji, A. D. New (NS), Schiff Base with a Flexible Spacer. Synthesis and Structura Characterization of Its First Coordination Polymer $\left[\mathrm{Cu}_{2}(\mu\right.$. I) ${ }_{2}(\mu \text {-(thio) } x \text { dapte) }]_{n}$ (1). Inarg. Chim. Acta 2009, 362 1637-1640. DOI: 10.1016/j.ica.2008.07.002

[3] Song, Y. I; Kwak, H; Lee, Y. M; Kim, S. H; Lee, S. Hz; Park B. Ki Jun, I. Y.; Yu, S. M; Kim, C.; Kim, S.-J; Kim, Y. Metal. Directed Supramolecular Assembly of Metal (II) Bennates $(\mathrm{M}=\mathrm{Co}, \mathrm{Ni}, \mathrm{Cu}, \mathrm{Zn}, \mathrm{Mn}$, and $\mathrm{Cd})$ with 4, 4-Bipyridine: Effects of Metal Coordination Modes and Novel Catalytic Activities Polyhairon 2009, 28, 1241-1252 DOE 10.1016/j.poly.2009.02 014 .

[4] Du, M; Zhas, X.-J. $\left\{\left[\mathrm{Cu}(\mathrm{Bipy})_{25}\left(\mathrm{H}_{2} \mathrm{O}\right)\right]\left(\mathrm{ClO}_{4}\right)_{2}\right.$ $\left.\left(\mathrm{H}_{2} \mathrm{O}\right) \cdot\left(\mathrm{CH}_{3} \mathrm{OH}\right)_{1.5}\right\}_{n}$ (Bipy $=4,4$-bipyridine): Organic Temple Effect in Formation of a Novel Bilayer Coordination Polymer with Large Chiral Channels Inarg. Chem. Commun. 2004, 7, 1056-1060. DOE 10.1016/j.inoche.2004.07.020.

[5] Huang, F.-P.; Tian, J--L.; Gu W.; Yan, S.-P. Three 3D Cu(II) Coordination Polymers Constructed from 1, 2, 4, 5 Benzenetetracarboxylate Acid and Three Positional Isomeric Ligands. Inorg. Chem. Commuen. 2010, 13, 90-94. DOE 10.1016/ j.inoche 2009.10.025.

[6] Kim, S. H.; Park, B. K.; Song, Y. J; Yu, S. M; Koo, H. G.; Kim, E. Y; Poong J. L; Lee, J. H. Kim, C.; Kim, S.J.; Kim, Y. Construction of Crystal Structures of Metal (II)-Benzoates $(\mathrm{M}=\mathrm{Mn}, \mathrm{Ni}, \mathrm{Co}, \mathrm{Cu}, \mathrm{Zn}$, and $\mathrm{Cd})$ and 1,2 -bis (4-pyridyl) Ethane: Effects of Metal Coordination Modes and Their Catalytic Activities Inorg. Chim Acta 2009, 362, 41 19-4126. DOE: $10.1016 /$ j.ica.2009.06.008.

[7] Xu, L.; Wang, E.; Peng. Iz Huang, R. A Novel Coordination Polymer with Double Chains Structure: Hydrothermal Syntheses, Structures and Magnetic Properties of $\left[\mathrm{Cu}(\mathrm{Phen})\left(\mathrm{H}_{2} \mathrm{O}\right)_{2} \mathrm{SO}_{4}\right]_{\text {n }}$ (Phen $=1$, 10-phenanthroline). Inarg Chem. Cammien. 2003, 6, 740-743. DOE 10.1016/S1387. $7003(03) 00055-8$

[8] Gag, L.; Zhao, B.; Li, G.; Shi, Z.; Feng, S. Mixed Solvothema Synthesis and $\mathrm{X}$-ray Characterization of a Layered Copper Coordination Polymer, $\mathrm{Cu}\left(\mathrm{H}_{2} \mathrm{O}\right)(1, \quad 3-\mathrm{BDC}) \cdot \mathrm{H}_{2} \mathrm{O}$ (BDC-benzenedicarboxylate). Inorg. Chem. Cammior. 2003, 6, 12.9-1251. DOI: $10.1016 / 51387-7003(03) 00242-9$.

[9] Jin, S.-W 3 . Chen, W.-Z Synthesis and Characterization of $\mathrm{Cu}$ (II), $\mathrm{Co}$ (II) and $\mathrm{Ni}$ (II) Coordination Polymers Containing bis (imidazolyl) Ligands. Pobhedrun 2007, 26, 3074-3084. DOE 10 1016/j.poly.2007.02029.

[10] Goforth, A. M.; Gerth, K.; Smith, M. D; Shotwell, S.; Bunz, U. H: Zar Loye, H.C. Channel-Containing Structures Generated from Linear Coordination Polymer Chains Containing $\mathrm{N}, \mathrm{N}^{\prime}$-Bidentate Ligands and $\mathrm{Cu}-\mathrm{Cu}$ Dimetal Units Solid State Sci. 2005, 7, 1083-1095. DOL 10.1016/j.solidstates. ciences 2005.03 .006 .

[11] Xiong, K; Jiang, F; Gai, Y; Yuan, D; Chen, L.; Wu, M; Su, K. Hong M. 'Truncated Octahedral Coordination Cage Incorporating Six 'Tetranuclear-Metal Building Blodks and 'Twelve Linear Edges. Chem. Sa. 2012, 3, 2321-2325. DOE 10 $1039 / \mathrm{c} 2 \mathrm{~s} 20264 \mathrm{f}$

[12] Zhang, $\mathrm{H}_{-} ; \mathrm{Pu}, \mathrm{W}_{-}$Xiong, T; Li, $\mathrm{Y}_{-}$Z Zhou, $\mathrm{X}_{\text {; }}$ Sun, K.; Liu, QThang, Q. Copper-Catalyzed Intermolecular Aminocyanation and Diamination Of Alkenes Angew. Chom. Int. Ed. 2013, 52, 2529-2533. DOI: $10.1002 /$ anie. 201209142 .

[13] Thang, L.; Bi, X.; Guan, X.; Li, X.; Liu, Q; Barry, B. D; Liao, P. Chemorelective Oxidative $\mathrm{C}$ (CO)- $\mathrm{C}$ (methyl) Bond Cleavage of Methyl Ketones to Aldehydes Catalyzed by $\mathrm{CuI}$ with Molecular Oxygen. Angew. Chem. 2013, 125, 11513-11517. DOL 10.1002/ ange 201305010 .

[14] Dhayal, R. S.; Liao, J.-H; Lin, Y.-R.; Liao, P.-K.; Kahlal, S. Saillard, J-Y F $_{3}$ Liı, C. A Nanospheric Polyhydrido Copper Cluster of Elongated Triangular Orthobicupola Array. Liberation of $\mathrm{H}_{2}$ from Solar Energy. J. Am Chem Soc 2013, 135, 4704-4707. DOE $10.1021 / j a 61576 \mathrm{~s}$. 
[15] Khnayzer, R. S; McCusker, C. E; Olaiya, B. S; Castellano, F. N. Robust Cuprous Phenanthroline Sensitiver for Solar Hydrogen Photocatalysis J. Am. Cham. Soc 2013, 135, 19068-14070. DOL: $10.1021 / j a 607816 f$

[16] Liu, K.; Sun, Y, Deng, L.; Cao, F.; Han, J; Wang, L. Cu(II) Coordination Polymers Constructed by Tetrafluoroterephthalic Acid and Varied Imidazole-Containing Ligands Syntheses Structures and Properties J. Solid State Chem 2018, 258, 24-31. DOL: 10.1016/j.jssc.2017.10.002.

[17] Lil, K; Deng, L.; Zhang, $Y_{\text {; }}$ Jiao, S.; Geng, Y.; Wang, L. Coordination Behavior of bis-Imidenle and Various Carboxylate Ligands 'Towards Zn(II) and Cd(II) ions: Synthesis, Structure, and Photoluminescence Stuxly. Grystals 2018, 8, 236. DOI: $10.3390 /$ cryst $\$ 060236$.

[18] Liu, $\mathrm{K} ; \mathrm{Hu}, \mathrm{H} ;$; Sun, J; Zhang, $\mathrm{Y}_{;}$Han, J; Wang, L. pH-Value. Controlled Assembly of Photoluminescent Zinc Coordination Polymers in the Mixed-Ligand System. J. Mol Struct. 2017, 1134, 174-179. DOE: 10.1016/jmolstruc.2016.12.075.

[19] Kawaguchi, S. Variety in the Coordination Modes of B-Dicarbonyl Compounds in Metal Compleses. Coardinat Chem. Rev. 1986, 70, 51-84. DOE 10.1016/0010-8545(86) $80035-2$.

[20] Shan, Z; Stach, E; Wienorek, J; Knapp, J; Follstaedt, D; Mao, S. Grain Boundary-Mediated Plasticity in Nanocrystalline Nicked. Saince 2004, 305, 654-657. DOE 10.1126/science. 1098741 .

[21] Fard, M. J. S.; Hayati, P.; Naraghi, H. S.; Tabeie, S. A. Synthesis and Characterization of a New Nano Lead (II) 0-D Coordination Supramolecular Compound: A Precursor to Produce Pure Phase Nano-Sired Lead (II) Oxide. Ultrisan. Sanodhem 2017, 39, 129. DOE: 10.1016/j.ultsonch.2017.04.023.

[22] Fard, M. J. S; Hayati, P, Firoozadeh, A.; Jancrak, J. Ultrasonic Synthesis of 'Two New Zinc (II) Bipyridine Coordination Polymers: New Precursors for Preparation Of Zinc (II) Oxide Nano-Particles Utrason. Sonochem. 2017, 35, 502-513. DOL 10. 1016/j.ultsonch.2016.1 1.009,

[23] Akhturi, K; Morsali, A.; Retaileau, P. Effect of 'T'wo Sonodiemical Procedures on Achieving to Different Morphologies of Lead(II) Coordination Polymer NanoStructures. Uftrisan. Sanocham. 2013, 20, 1428-1435. DOL 10 $1016 / j$.ultsonch.2013.03.013.

[24] Fard, M. J. S; Hayati, P. Firocradeh, A; Jancrak, J. Sonochemical Synthesis of T'wo New Zinc(II) 1, 10-Phenanthroline Coordination Supramolecular Compounds: New Prearsors to Produce NanoSized Zinc (II) Oxide Ulitravn Sanodiam. 2017, 37, 286-297. DOE 10.1016/j.ul tsonch 2017.01.020.

[25] Abbusi, A. R: Morsali, A. Influence of Solvents on the Morphological Properties of AgBr Nano-Structures Prepared Using Ultrasound Irradiation. Ultrasan. Sonodhem. 2012, 19, 5\%0-554. DOE 10.1016/j.ultsonch.201 L.08.002.

[26] Goher, M. A. S; Abu-Youssef, M. A. M.; Mautner, F. A. Crysta Structure Investigation of Copper(II) Thiocyanato and Cobalt (III) Axido Complexes of Picolinic Add; [Cu (Pic) $\left.(\mathrm{SCN})\left(\mathrm{H}_{2} \mathrm{O}\right)_{2}\right] \cdot 2 \mathrm{H}_{2} \mathrm{O}$ and $\left[\mathrm{Na}_{2} \mathrm{Co}(\mathrm{Pic})_{2}\left(\mathrm{~N}_{3}\right)_{2}\left(\mathrm{H}_{2} \mathrm{O}\right)_{6}\right][\mathrm{Co}$ (Pic) $\left.{ }_{2}\left(\mathrm{~N}_{3}\right)_{2}\right] \cdot 2 \mathrm{H}_{2} \mathrm{O}$. Zeitsdunft Für Naturforscheng $B$ 1993, 48, 1795-1800. DOE: 10.1515/mb-1993-1216.

[27] Cao, S.; Jiang, J\& Zhu, B.; Yu, J. Shape-Dependent Photocatalytic Hydrogen Evolution Activity Over a Pt Nanoparticle Coupled $\mathrm{gC}_{3} \mathrm{~N}_{4}$ Photocatalyst. Phys. Chem. Chem Phys 2016, 18, 19457-19563. DOI: 10.1039/C6CP02832B.

[28] Khan, L; Ali, S.; Mansha, M.; Qurashi, A. Sonochemical Assisted Hydrothermal Synthesis of Pseudo-Flower Shaped Bismuth Vanadate $\left(\mathrm{BiVO}_{4}\right)$ and Their Solar-Driven Water Spliting Application. Ultrason. Sanodhem. 2017, 36, 386-392 DOI: $10.1016 / j . u l$ tsonch.2016.12.014.

[29] Bang. J. H.; Suslick, K. S. Applications of Ultrasound to the Synthesis of Nanostructured Materials. Adv. Mater. 2010, 22 1039-1059. DOL: 10.1002/adma.200909093.

[30] Olistu, K.; Asholdumar, M.; Grieser, F. Sonochemical Synthesis of Gold Nanoparticles: Effects Of Ultrasound
Frequency. J. Phys Chem B 2005, 109, 20673-20675. DOL 10. $1021 /$ jp05 49374

[31] Siedl, N-; Raumann, S. O-z Elser, M. J; Diwald, O. Particke Networls from Powder Mixtures Generation of $\mathrm{THO}_{2}-\mathrm{SnO}_{2}$ Heterojunctions Via Surface Charge-Induced Heterosggregation. J. Phys. Cham. C 2012, 116, 22967-22973. DOI: $10.1021 / \mathrm{jp} 307737 \mathrm{~s}$

[32] de Silva, G. T;; Carvalho, K. T.; Lopes, O F; Ribeiro, C $\mathrm{g}_{3} \mathrm{~N}_{4} / \mathrm{Nb}_{2} \mathrm{O}_{3}$ Heterostructures Tailored by Sonochemica Synthesis Enhanced Photocatalytic Performance in Oxidation of Emerging Pollutants Driven by Visible Radiation. App. Catal B Environ. 2017, 216, 70-79. DOE: 10.1016/japcatb.2017.05.038.

[33] Koch C. C. Duxtility in Nanostructureal and Ultra FineGrained Materials: Recent Evidence for optimism. Jmum. 2003, 18, 9-20. DOL 10.4028/www.scientific.net/JMNM.18.9.

[34] Jun, Y-w; Sea, J-w; Oh, S. J.; Chenn, J. Recent Advances in the Shape Control Of Inorganic Nano-Building Blodks Coardinat. Cham. Rev. 2005, 249, 1766-1775. DOE: 10.1016/j.ccr.2004.12.008.

[35] Shi, H. Qi, L.; Ma, J; Cheng, H. Polymer-Directed Synthesis of Penniform BaWO4 Nanostruxtures in Reverse Micelles J. Am. Chem. Soc. 2003, 125, 3450-3451. DOL $10.1021 / j 3029958 \mathrm{f}$

[36] Kim, J. H.; Andeen, D; Lange, F. F. Hydrothermal Growth of Periodic, Single-Crystal ZnO Microrods and Microtunnels. Adv. Mater. 2006, 18, 2453-2457. DOE 10.1002/adma.200600257.

[37] Kuang, D; $X_{u 1,}$ A; Fang, $Y_{;}$Liu, H; Frommen, C; Fenske, D. Surfactant-Assisted Growth of Novel PbS Dendritic Nanostructures Via Facile Hydrothermal Process. Adv. Mater. $2003,15,1747-1750$. DOE $10.1002 /$ adma.200304623.

[38] Kim, F.; Connor, S.; Song, H.; Kuykendall, T.; Yang, P. Phatonic Gold Nanocrystals. Angew. Chem. 2004, 116, 3759-3763. DOL $10.1002 /$ ange. 20044216 .

[39] Lv, S; Li, P.; Sheng, J; Sun, W. Synthesis of Single Crystalline $\mathrm{BaCO}_{3}$ Nanostructures with Different Morphologies via a Simple PVP-Assisted Method. Mater. Lett. 2007, 61, 4250-4254. DOI: $10.1016 /$ j.matlet.2007.01.075.

[40] Hayati, P; Rervani, A. R; Morsali, A.; Retailleau, P; Garcia. Granda, S. Influences of Temperature, Power Ultrasound and Reaction 'Time on the Morphological Properties of 'Two New Mercury (II) Coordination Supramolecular Compounds Uitrason. Sanocham. 2017, 34, 968-977. DOL 10.1016/j-ultsonch.2016.07.019.

[40] Hayati, P,; Rervani, A. R.; Morsali, A.; Retailleau, P.; Garcia Granda, $S$. Influences of Temperature, Power Ultrasound and Reaction 'Time on the Morphological Properties of 'Two New Mercury (II) Coordination Supramolecular Compounds. Ufitrason. Sanochem. 2017, 34, 968-977. DOL 10.1016/j.ult. sonch.2016.07.019.

[40] Hayati, P.; Rervani, A. R.; Morsali, A.; Retailleau, P.; García. Granda, S. Influences of Temperature, Power Ultrasound and Reaction 'Time on the Morphological Properties of 'Two New Mercury (II) Coordination Supramolecular Compounds Ultrason. Sanocham. 2017, 34, 968-977. DOE 10.1016/j.ult. sonch.2016.07.019.

[41] Hayati, P.; Rezvani, A.; Morsali, A.; Retailleau, P.; Centore, R. Survey of Temperature, Reaction Time and Ultrasound Irradiation Power on Sonochemical Synthesis of 'Two New Nanostructured Lead (II) Coordination Supramolecule Compounds Ulitrason. Sanochom. 2017, 35, 81-91. DOL 10. $1016 /$ j.ultsonch.2016.09.005.

[42] Abtasi, A. R.; Morsali, A. Syntheses and Characterization of AgI Nano-Structures by Ultrasonic Method: different Morphologies under Different Conditions Ulinason. Sanodhem 2010, 17, 572-578. DOE: $10.1016 /$ j.ultsonch.2009.11.002.

[43] Abbasi, A. R; Morsali, A. Formation of Silver lodide nanopar ticles on silk Fiber by Means of Ultrasonic Imadiation. Uitrason. Sanocham. 2010, 17, 704-710. DOE 10.1016/j-ultsonch.2010.01.002.

[44] Hayati, P; Rervani, A. R; Morsali, A; Retailleau, P. Ultrasound Imadiation Effect on Morphology and Size of 'Two New Potessium 
Coordination Supramolecule Compounds Uifrusan. Sarvdham 2017, 34, 195-205. DOE: 10.1016/j.ul tsonch 2016.05.031.

[45] Hayati, P, Rezvani, A. R.; Morsali, A.; Molina, D. R; Geravand, S.; Suarez-Garcia, S.; Villaecija, M. A. M.; Garcia-Granda, S. Mendoza-Meroño, R; Retailleau P. Sonochemical Synthesis, Charaderization, and Effects of Temperature, Power Ultrasound and Reaction Time on the Morphological Properties of 'Two New Nanostructured Mercury(II) Coordination Supramolecule Compounds Uftrasan. Sanochom. 2017, 37, 382-393. DOI: 10.1016/j.ul tsonch.2017.01.021.

[46] Hou, L.; Li, D.; Shi, W.-J; Yin, Y.-G.; Ng, S. W. Ligand Controlled Mixed-Valence Copper Rectengular Grid-Type Coordination Polymers Based on Pyridylterpyridine. Inarg. Chem. 2005, 44, 7825-7832 DOE: 10.1021/ic050558d.

[47] Chen, G.; Rai, Z P.; Qu, S. J. Catena-Poly [[dipyridylcopper (II)]-di- $\mu$-thiocyanato]. Acta Crystallograph. 2005, 61, m2718-m2719.

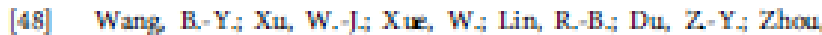
D.-D.; Zhang, W.-X.; Chen, X.-M. Restraining the Motion of a Ligand for Modulating the Structural Phase Transition in 'Two Isomorphic Polar Coordination Polymers. Dalton Trans. 2014, 43, 9005-9011. DOI: 10.1039/CADT00675E.

[49] Vanōn, J; 'Trívniček, Z; Marek, J; Herchel, R. Synthesis, Spectral (UV-Vis, IR, ESI-MS), Magnetic and Structura Characterizations, and the Antimicrobial Effect of Potassium Isothiocyanato-(N-Salicylidene-Amino-Acidato) Cuprates I nargChim Acta 2010, 363, 3887-3896. DOL 10.1016/j.ica.2010.07. 041.

[50] Rigaku. CrystalClear-SM Expert 2.1 b43. Rigaku Corporation: Tokyo, Japan, 2014

[51] Sheldrick, G. M. SHEL.XT: Integrating space group determin ation and structure solution. Ada Crystallogr. Sect. A: Found Adv .70, 2014 C1437

[52] Spek, A. L. Structure validation in chemical crystallography. Acti Crystallogr. D Biol Crystallogr. 2009, D65, 148-155. DOL $10.1107 / 509074490804362 \mathrm{X}$.

[53] SADABS, Bruker-Nonius: Delft, The Netherlands, 2002.

[54] A; Altomare, M. C; Burla, M.; Camalli, G. L.; Cascarano, C. Giacovazzo, A.; Guagliardi, G. G.; Molitemi, G.; Polidori, R.Spagna, J. SIR 97: A New T'ool for Crystal Structure Determination and Refinement. J. Appl Crystillogr. 1999, 32 115-119. DOI: $10.1107 / 90021899898007717$

[55] Sheldrick, G. M. A Short History of SHELX. Acta Crystallogr-. A, Found. Crystillogr 2008, 64, 112-122 DOL 10.1107 S0 108767307043930 .

[56] Farrugia, L. J. WinGX and ORTEP for Windows : An Uphete 1. Appl Crystallogr. 2012, 45, 849-854. DOL 10.1107/ S00218998 12029111

[57] Mercury 1.4.1, Copyright Cambridge Crystallographic Data Centre, 12 Union Rowd, Cambridge, CB2 IEZ, UK, 2001-2005.

[58] Dolomanov, O. V ; Bourhis, L. Ji; Gildea, R Ji Howard, J. A. Puschmann, H. OLEX2: A Complete Structure Solution, Refinement and Analysis Program. J. Appl Crystallogr. 2009, 42, 339-341. DOE $10.1107 / 50021899908042726$.

[59] Suslick, K. S. Sonochemistry. Science 1990, 247, 1439-1445. DOL $10.1126 /$ science. 247.4949 .1439$.

[60] Suslick, K. S; Flannigan, D. J. Inside a Collapsing Bubble: sonoluminescence and the Conditions during Cavitation. A rouk Rev. Phys. Chem. 2008, 59, 659-683. DOL 10.1146/annurev. phys chem59.032607.093739.

[61] Blatov, V. A.; Shevchenko, A. P; Proserpio, D. M. Applied Topological Analysis of Crystal Structures with the Program Package ToposPro. Crystal Growth Design 2014, 14, 3576-3586. http://topospracom. DOE: $10.1021 / \mathrm{cg} 50049$ sk.

[62] Alexandrov, E. V $;$ Bhatov, V. A.; Kochethov, A. V $;$ Proserpio D. M. Underlying Nets in Three-Periodic Coordination Polymers: topology, Taxonomy and Prediction from a Computer-Aider Analysis of the Cambridge Structural Datahese. CrystEngCamm 2011, 13, 3947-3958. DOL 10.1039/ coce $00636 \mathrm{j}$.
[63] CnesnN, E; Wome N. C. Crystal Habit of Synthetic Ghalcanthite (Copper Sulfate Pentahydrate) as Related to Position and Orientation in Growth Solution. Am. Mineral 1974, 59, 1105-1112

[64] Urgut, O; Ozturk, L; Banti, C; Kourkoumelis, N; Manoli, M.; Tasiopoulos, A; Hadjikaloou, S. New Antimony(III) Halide Complexes with Dithiocarbamate Ligands Derival from Thiuram Degradation: 'The Effect of the Molecule's Close Contacts on in Vitro Cytotaxic Activity. Mater. Sci Eng. C 2016, 58, 396-408. DOI: 10.1016/j.msec.2015.08.030.

[65] Urgut, O; Oxturk, L; Banti, C.; Kourkoumelis, N-; Manoli, M. Tasiopoulos, A; Hadjilakou, S. Addition of Tetraethylthiuram Disulfide to Antimony (III) Iodide; Synthesis, Characterization and Biologial Activity. Inarg Chim. Acta 2016, 443, 141-150. DOE: 10.1016/jica.2015.12029.

[66] Spackman, M. A; McKinnon, J. J. Fingerprinting Intermolecular Interactions in Molecular Crystak CrystEngComm 2002, 4, 378-392 DOI: 10.1039/B203191B.

[67] Bouaziz, E; Hassen, C. B; Chniba-Boudjada, N-; Daoud, A. Mhiri, 'T'; Boujelbene, M. Crystal Structure, Hirshfeld Surfece Analysis, Vibrational, Themnal Behavior and UV Spectroscopy of (2, 6-Diaminopyridinium) Dihydrogen Arsenate. J. Mol Stract. 2017, 1145, 121. DOL: 10.1016/j.molstruc 2017.05.043

[68] Jayatilaka, D; McKinnon, Jis Spaclanan, M. Towards Quantitative Analysis of Intermolecular Interactions with Hirshfeld Surfaces. Chem. Commuen. 2007, 37, 3814. DOL 10 $1039 / \mathrm{b} 704980 \mathrm{c}$

[69] Spackman, M. A.; Jayatilala, D. Hirshfeld Surface Analysis CrystEngComm 2009, 11, 19-32. DOL 10.1039/B818330A.

[70] Bitzer, R. S; Visentin, L. C.; Hörner, M; Nascimenta, M. A. C. Filgueiras, C. A. L. On the Molecular and Supramolecular Properties of $\mathrm{N}, \mathrm{N}^{\prime}$-Disulxtituted Iminoisoindolines Synthesis, Spectroscopy, X-Ray Structure and Hirshfeld Surface Analyses, and DFT Calculations of 'Two (E)-N, N'Bis(Aryl)Iminoisoindolines (Aryl $=2$ 'Tert-Butylphenyl or PerfluorophenyI). J. Mol. Stnat 2017, 1130, 165. DOE 10.1016/ j.molstruc.2016.10.029.

[71] Majundar, D; Biswas, J. K; Mondal, M.; Babu, M. S; Metre, R. K. Das, S; Bankura, K; Mishra, D. Coordination of N, ODonor Appended Schiff Rase Ligand $\left(\mathrm{H}_{2} \mathrm{~L}_{1}\right)$ towards Zinc(II) in Presence of Pseudohalides: Syntheses, Crystal Structures, Photol uminescence, Antimicrobial Activities and Hirshfeld Surfices. J. Mal Struct. 2018, 1155, 745-757. DOE 10.1016/j. molstruc:2017.11.052.

[72] Majundar, D; Dey, S; Sreejith, S. S; Biswas, J. K.; Mondal, M. Shukh, P; Das, $S_{-i}$ Pal, 'T'; Das, D; Bankura, K; Mishra, D. Syntheses, Crystal Structures and Photo Physical Aspects of Azido-Bridged Tetran uclear Cadmium(II) Complexes: DFI/TD. DFI, Thermal, Antibacterial and anti-Biofilm Properties. $J$. Mol. Struct. 2019, 1179, 694-708. DOL: 10.1016/j.molstrux.2018. 11.010

[73] Majundar, D. Jz Dey, S.; Sreekumar, S. S.; Das, S; Das, D. Metre, R. K; Bankura, K. Mishra, D. Nitrato, PseudohaloLinked Zn(II)/Cd(II) Schiff-Base Complexes with 1, 3-Diimine Spacer Group Syn theses, Crystal Structures, DFT, 'TD-DFT and Fluorescence Stulies Chem Seled 2018, 3, 12371-12382 DOI $10.1002 / \mathrm{slct.201} 802996$.

[74] Goher, M. A. S; Abu-Youssef, M. A. M; Mautner, F. A. Crystal Structure Investigation of Copper(II) Thiocyanato and Cobalt (III Axido Complexes of Picolinic Acid; [Cu (Pic) $(\mathrm{SCN})(\mathrm{H} 2 \mathrm{O}) 2] \cdot 2 \mathrm{H} 2 \mathrm{O}$ and $[\mathrm{Na} 2 \mathrm{Co}(\mathrm{Pic}) 2(\mathrm{~N} 3) 2(\mathrm{H} 2 \mathrm{O}) 6][\mathrm{Co}$ (Pic)2(N3)2]. 2H2O. Zeitsduift Für Naturforschung B 1993, 48, $1795-1800$

[75] Daković, M.; Japlizić, Z; Kozlevãar, B; Popović, Z. Association of Copper(II) Isonicotinamide Moieties vis Different Anionic Bridging Ligands: Two Paths of Ferromagnetic Interaction in the Avide Coordination Compound. Pabyhedrun 2010, 29, 1910-1917. DOI: 10.1016/j.poly.2010.02.040.

[76] Das, L. K.; Dizz, C.; Ghosh, A. Antiferromagnetic Mixed. Valence $\mathrm{Cu}(\mathrm{I})-\mathrm{Cu}$ (II) Two-Dimensional Coordination Polymers 
Constructed by Double Oximato Bridged Cu(II) Dimers and CuISCN Based One-Dimensional Anionic Chains. Crystal Growth Design 2015, 15, 3939-3949. DOI: 10.1021/acs.cgd. $5 b 00560$.

[77] Kabeiovovi, M.; Dunaj-Jurōo, M.; Soldanova, J. Crystal and Molecular Structure of Bis (4-Bromopyridine) Dithiocyanate Copper(II). Inarg. Chim Acta 1987, 130, 105-111. DOL 10 $1016 / 50020-1693(00) 55937-X$

[78] Koriskova, Z; Koxisek, J; Kabesova, M. Three Different Copper(II) Coordination Polyhedra in the Crystal Structure of Bis (4-Picoline) Dithiocyanato Copper(II) Complex, $[\mathrm{Cu}(4$ Pic $)_{2}(\mathrm{NCS})_{2}$; Experimental Evidence of a New 'Type of Mutual Influence of Ligands in Complexes. Pobyhedrun 1990, 9, 1029-1034.

[79] Malecki, J; Machura, B.; Świtlicla, A; Kusz, J. X-Ray Studies, Spectroscopic Characterization and DFT Calculations for $\mathrm{Mn}$ (II), $\mathrm{Ni}$ (II) and $\mathrm{Cu}$ (II) Complexes with 2-Benzoylpyridine. Palyhedrun 2011, 30, 410-418. DOE 10.1016/j-poly_2010.11.013.

[so] Wrielt, M.; Nither, C. In Situ Solid State Formation of Copper(I) coordination Polymers by Thermal Reduction of Copper(II) Precursor Compounds structure and Reactivity of $\left[\mathrm{Cu}(\mathrm{NCS})_{2} \quad(\text { Pyrimidine })_{2}\right]_{\mathrm{s}}$ Dalen Trans 2009 , 46,10192-10198. DOL 10.1039/b909s3sk.

[81] Cobeljić, B; Pevec, A.; Turel, L; Spasojević, V; Miläić, M; Mitić, D; Sladić, D.; Andelavić, K. Analysis of the Struchures of the $\mathrm{Cu}(\mathrm{I})$ and $\mathrm{Cu}$ (II) Complexes with 3-Acetylpyridine and 'Thiocyanate. Polyhedran 2014, 69, 77-83. DOE 10.1016/j.poly. 2013.11.027.

[82] Karadag, A.; Yilmaz, V. Ts; Thoene, C. Di-and 'Triethanolamine Complexes of $\mathrm{Co}$ (II), $\mathrm{Ni}$ (II), $\mathrm{Cu}$ (II) and $\mathrm{Zn}$ (II) with 'Thiocyanate: synthesis, Spectral and Themal Studies. Crysta Structure of Dimeric Cu (II) Complex with Deprotonated Diethanolamine, $\left[\mathrm{Cu}_{2}(\mu \text {-Dea })_{2}(\mathrm{NCS})_{2}\right]$. Polyhedron 2001, 20, 635-641. DOE 10.1016/\$0277-5387(01)00720-3.

[83] Mikuriya, M.; Kida, S.; Murase, L Preparation and Crystal Structures of Binuclear Copper(II) Complexes of N, N, N ", $\mathrm{N}^{3}$-Tetrakis (2-Aminoethyl) $1, \quad 4, \quad 8, \quad 11$ 'Tetraazacyclotetradecane Containing Azide, Cyanate, or 'Thiocyanate Ion. Bcsj. 1987, 60, 1355-1359. DOE 10.1246/bosj. 60.1355 .

[84] Machura, B; Świtlicka, A.; Mrozińsld, JA Kalińsla, B. Kruszynski, R Structural Diversity and Magnetic Properties of Thiocyanate Copper(II) Complexes Polyhedron 2013, 52, 1276-12S6. DOE 10.1016/j.poly-201206.019.

[85] Dominguez, S; 'Torres, Ji; González-Platas, J.; Hummert M. Schumann||, $\mathrm{H}_{-}$Kremer, C. Themodynamic Stability and Crystal Structure of Lanthanide Complexes with di-2-Pyridyl Ketone. J. Courdinat Chem. 2009, 62, 108-119. DOL 10.1080 00958970802474797 . 